\title{
Present and Future of Bronchopulmonary Dysplasia
}

\author{
Luca Bonadies ${ }^{1}{ }^{\complement}$, Patrizia Zaramella ${ }^{1}\left(\mathbb{D}\right.$, Andrea Porzionato ${ }^{2}$, Giorgio Perilongo ${ }^{3}$, \\ Maurizio Muraca ${ }^{4}$ and Eugenio Baraldi ${ }^{1, *}$
}

1 Neonatal Intensive Care Unit, Department of Women's and Children's Health, University of Padova, 35128 Padova, Italy; lucabonadies@hotmail.it (L.B.); patriz.zaramella@gmail.com (P.Z.)

2 Human Anatomy Section, Department of Neurosciences, University of Padova, 35128 Padova, Italy; andrea.porzionato@unipd.it

3 Department of Women's and Children's Health, University of Padova, 35128 Padova, Italy; giorgio.perilongo@unipd.it

4 Institute of Pediatric Research "Città della Speranza", Stem Cell and Regenerative Medicine Laboratory, Department of Women's and Children's Health, University of Padova, 35128 Padova, Italy; muraca@unipd.it

* Correspondence: eugenio.baraldi@unipd.it; Tel.: +39-049-821-3560; Fax: +39-049-821-3502

Received: 15 April 2020; Accepted: 18 May 2020; Published: 20 May 2020

\begin{abstract}
Bronchopulmonary dysplasia (BPD) is the most common respiratory disorder among infants born extremely preterm. The pathogenesis of BPD involves multiple prenatal and postnatal mechanisms affecting the development of a very immature lung. Their combined effects alter the lung's morphogenesis, disrupt capillary gas exchange in the alveoli, and lead to the pathological and clinical features of BPD. The disorder is ultimately the result of an aberrant repair response to antenatal and postnatal injuries to the developing lungs. Neonatology has made huge advances in dealing with conditions related to prematurity, but efforts to prevent and treat BPD have so far been only partially effective. Seeing that BPD appears to have a role in the early origin of chronic obstructive pulmonary disease, its prevention is pivotal also in long-term respiratory outcome of these patients. There is currently some evidence to support the use of antenatal glucocorticoids, surfactant therapy, protective noninvasive ventilation, targeted saturations, early caffeine treatment, vitamin $\mathrm{A}$, and fluid restriction, but none of the existing strategies have had any significant impact in reducing the burden of BPD. New areas of research are raising novel therapeutic prospects, however. For instance, early topical (intratracheal or nebulized) steroids seem promising: they might help to limit BPD development without the side effects of systemic steroids. Evidence in favor of stem cell therapy has emerged from several preclinical trials, and from a couple of studies in humans. Mesenchymal stromal/stem cells (MSCs) have revealed a reparatory capability, preventing the progression of BPD in animal models. Administering MSC-conditioned media containing extracellular vesicles (EVs) have also demonstrated a preventive action, without the potential risks associated with unwanted engraftment or the adverse effects of administering cells. In this paper, we explore these emerging treatments and take a look at the revolutionary changes in BPD and neonatology on the horizon.
\end{abstract}

Keywords: bronchopulmonary dysplasia; extracellular vesicles; mesenchymal stem cells; mesenchymal stromal cells; neonatal ICU

\section{Background}

Bronchopulmonary dysplasia (BPD) was first described by Northway [1] in 1967. Although more than 50 years have since gone by [2], this disease still lacks a comprehensive definition and, more importantly, a definitive cure.

Recent decades have seen enormous improvements in neonatal intensive care and in the development of innovative strategies that have led to a marked increase in the survival rates of 
preterm newborns, and especially those born at an extremely low gestational age. The burden of BPD has remained unchanged, however, even though the course of this disease has probably been improved. Despite prenatal and postnatal interventions, BPD remains the most common and severe chronic respiratory illness among preterm-born infants. Its incidence, defined as oxygen use at 36 weeks' postmenstrual age or at discharge/transfer if before 36 weeks in infants who survived to 36 weeks, ranges from $15 \%$ to $35 \%$ among those born at $<32$ weeks of gestation (WG), and has not changed over the past two decades. This result is the consequence of an improved survival rate; recently, many infants that would have died decades ago now survive developing BPD [3]. The challenges posed by BPD-related morbidity are consequently rising, as are the public health costs associated with prematurity and its comorbidities (neonatal sepsis, adverse neurodevelopmental outcomes, retinopathy of prematurity, and long-term respiratory complications extending into adulthood). The main cause of death in BPD patients is pulmonary hypertension, which is associated with four- to five-fold higher odds of infant mortality [4] and morbidity [5].

Taken together, BPD-related problems pose a huge and costly public health challenge, both before discharge and afterwards at home. Multiple services are involved in a BPD patient's management (respiratory treatments, nutritional programs, neurodevelopmental stimulation, and so on [6]).

BPD is also a long-lasting disease, with effects that persist into adulthood [7]. A recent study examined the long-term effects of prematurity extending into adulthood (to age $30-45$ years) in a Swedish national cohort of more than 4 million singleton live births. The authors reported an inverse relationship between mortality risk and gestational age. The higher mortality rate seemed to be mediated by conditions such as diabetes, and cardiovascular and respiratory diseases. They concluded that preterm birth should be recognized as a chronic condition that requires long-term follow-up for the prevention and treatment of potential health sequelae into mid-adulthood [8]. BPD per se is related with higher mortality and morbidity, highlighting how former preterm BPD patients should be followed with even more care.

Hence, there is a strong interest in the feasibility of developing new prevention or treatment strategies for children born preterm.

This review outlines our present understanding of the future prospects for the prevention and treatment of BPD, based on our knowledge of the disease's pathogenesis, and on the current management of extremely low birth weight (ELBW) babies. This is not intended to be a systematic review of the literature. Articles were identified by searching PubMed using Medical Subject Headings, without using any selection or rejection criteria. Review articles are also cited.

\section{Definition and Diagnosis}

Bronchopulmonary Dysplasia is a chronic respiratory disease that affects a significant fraction of former extremely premature infants, this disease is a heterogeneous condition that develops on an extremely preterm lung exposed to different pathogenetic noxae.

The most often-mentioned consensus on how to diagnose BPD comes from the NICHD 2001 [9]. This definition considers two criteria: weeks of gestation (WG); and the need for supplemental oxygen beyond 28 days of life and/or oxygen dependence at 36 weeks post-menstrual age (PMA). To improve on this diagnosis, a physiological measure, like the "room challenge test", was suggested [10].

In 2018, the NICHD proposed a revision [11] of their definition, considering newer methods of noninvasive ventilation, a reclassification based on grades, and radiographic evidence of pulmonary parenchymal disease.

Though useful to neonatologists, these definitions do not seem to predict long-term outcomes. Those caring for patients with BPD are more interested in establishing new diagnostic criteria that can shed light on a patient's likely outcome. They also seek a more comprehensive definition of the disease, based on accurate clinical pathophysiology and the identification of biomarkers, rather than on interventions [12]. An international neonatal consortium [13] recently emphasized the concept that a definition of BPD should be clinically meaningful and strongly associated with the subsequent 
development of respiratory problems. The long-term effects of BPD are not all reached by 36 weeks after conception, making this age a less important milestone for the purposes of BPD stratification.

For this purpose, Isayama et al. [14] explored different timepoints to better diagnose BPD and predict respiratory outcomes, identifying the need for oxygen at 40 weeks PMA as the best predictor for serious respiratory morbidity, leaving an open field to the debate not only on which clinical data but also on which timepoint to be used.

Jensen et al. [15] recently reviewed the 18 existing definitions of BPD with a view to identify the most appropriate one for predicting childhood morbidity through 18-26 months. They found that the best definition (correctly predicting death or severe respiratory morbidity in $81 \%$ of cases) classified disease severity on ventilatory support at 36 weeks PMA alone, regardless of any supplemental oxygen use.

As Thebaud et al. [16] explained, a definition's predictive value can be improved by means of better objective measurements and biomarkers of lung injury and BPD, and by incorporating antenatal factors, such as intrauterine growth restriction (IUGR), a mother's hypertension or smoking, and male sex of her offspring. A single definition is unlikely to be able to address all the needs of neonatologists and pediatricians, caregivers, pharmacists, parents, and industries, nor is it likely to point towards significant endpoints. However, a more appropriate general definition would provide a better description of patients with BPD and enable more targeted preventive therapies.

\section{Pathology}

In infants with BPD, the pathological findings [17] include fewer secondary septa and alveoli, and sites of emphysema, meaning a smaller alveolar surface area, which is crucial to proper gas exchange. Angiogenesis is impaired with dysmorphic vessels and capillaries. Thickening of the muscle layer of the arterioles prompts an increase in vascular resistance and pulmonary hypertension. More fibrotic tissue is formed, with a widening and thickening of the interstitial spaces (Figure 1). This picture differs slightly from earlier descriptions (before surfactants became available), such as Northway's [1] report of injury, inflammation and fibrosis caused by volutrauma or barotrauma, and oxygen toxicity. Today's "new" BPD is the result of less severe injury in very immature lungs [18], but very little is known about the pathology of this "new BPD" - partly because fewer autopsies are being performed.

Angiogenesis and vessel branching reportedly drive alveolar growth in the lung, so the dysmorphic vascular architecture and angiogenesis described in BPD patients are important. Vascular channels have been described in infants who died of BPD. These vessels run through lobular sites normally occupied by veins towards the pulmonary arteries, then to the vasa vasorum of the pulmonary plexus and bronchial venous plexus [19]. These changes presumably provide the anatomical grounds for pulmonary hypertension in BPD, but these shunts may also serve as a "pop-up" valve to reduce the severity of pulmonary hypertension.

More collaboration between neonatologists and pathologists, a greater awareness of the importance of conducting autopsies on deceased BPD patients, high-resolution imaging, and increasingly reliable animal models could help us to shed more light on the still dark side of BPD. 


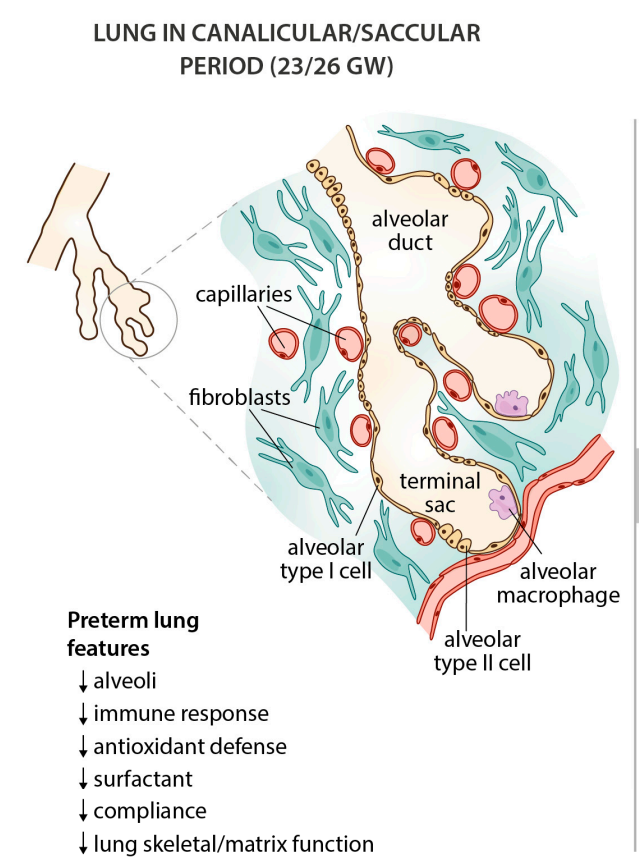

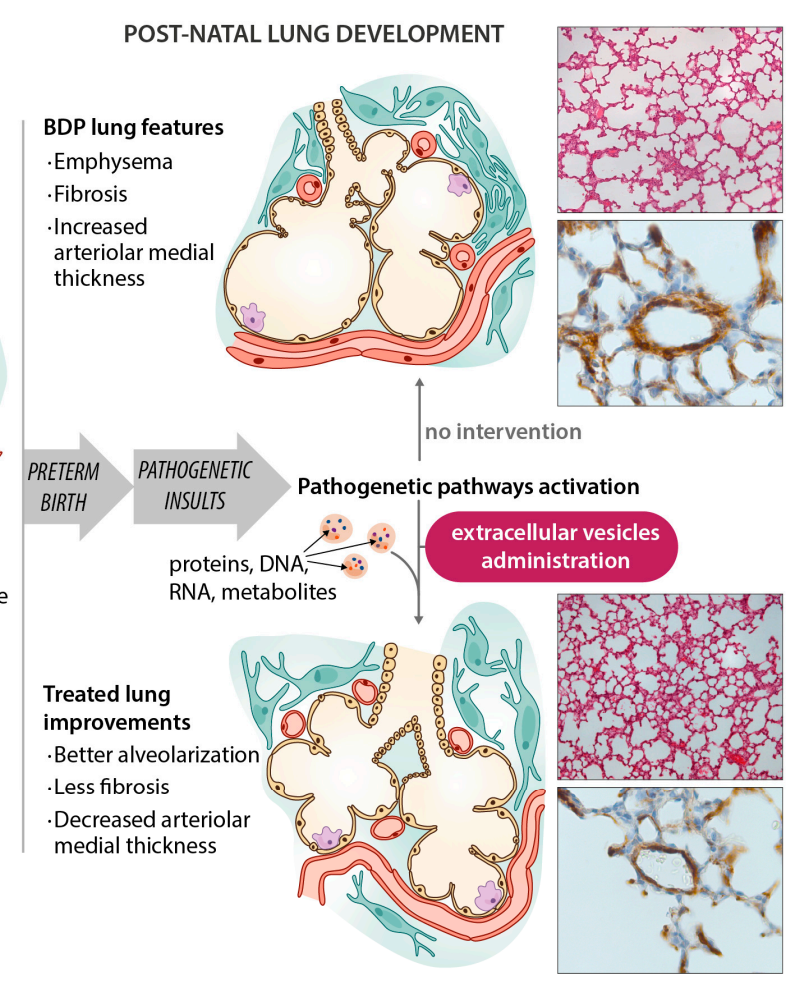

Figure 1. Schematic diagram of bronchopulmonary dysplasia (BPD) pathogenesis, with the main features of the disease in the preterm lung. Microphotographs show improvements in an experimental animal model (60\% hyperoxia-induced BPD in rat pups) after administering extracellular vesicles (EVs). Representative lung sections from hyperoxia-induced BPD (top right), and EV-treated animals (bottom right), showing effects of hyperoxia and EVs on alveolarization (upper side of microphotographs; stained with hematoxylin and eosin, scale bars $150 \mu \mathrm{m}$ ) and vessels less than $100 \mu \mathrm{m}$ in diameter (lower side of the microphotographs; stained with anti- $\alpha$-smooth muscle actin antibodies, scale bars $23.8 \mu \mathrm{m}$ ). Hyperoxia-induced changes in alveolarization (lower total number of alveoli; larger alveolar volume) and vascularization (increased medial thickness index) are minimized by the intratracheal administration of MSC-EVs.

\section{Pathogenesis}

A better understanding of how the premature infant's lung develops and of the pathogenesis of BPD could drive the search for novel treatments. Lung growth appears to be an intricate, highly orchestrated process involving multiple cell lines, and is guided by numerous different signaling pathways, which could all be disrupted by factors implicated in the onset of BPD [20].

At birth, most preterm newborns are in the saccular and canalicular phases of lung morphogenesis (assuming a viability limit at 24 weeks PMA). There have occasionally been reports of survivors born at 22 WG coping with breathing even during the canalicular phase of lung development [21].

Given the cellular architecture of an underdeveloped lung, low gestational age is the most significant determinant correlating with the onset of BPD. The premature lung has several features that predispose it to BPD, in addition to the well-known lack of surfactant. It also has: less-developed skeletal airway structures (extracellular matrix, collagen or elastin); less-developed antioxidant mechanisms; a lower compliance; and inadequate fluid clearance [22]. All these features make the lung more vulnerable, but many other factors contribute to causing BPD in such vulnerable tissue. BPD has a multifactorial etiology, with prenatal and postnatal mechanisms causing inflammation and injury. The consequent disruption of the lung's development also involves an aberrant repair mechanism. 


\section{Prenatal Risk Factors}

One significant variable contributing to the risk of BPD is intrauterine growth restriction (IUGR) [23,24]. The mechanisms behind this phenomenon seem to include an impaired growth of terminal airways and gas exchange units, but also a weaker expression of surfactant protein and mRNA, and possibly also the induction of an increased inflammatory response [24], but the mechanism underlying the correlation between BPD and IUGR is quite complex and still not completely understood. Bose et al. [25] suggested a multiple pathogenetic mechanism involving reduced lung growth, impaired angiogenesis, chronic fetal hypoxia with TGF-beta upregulation, and surfactant mRNA reduced expression. The hypothesis recently gaining importance is the "vascular hypothesis", as initially suggested by Abman [26] and recently widely explored [27].

Preeclampsia also seems to be related to a greater risk of BPD [28], although the precise mechanism of disruption involved is not known and could be indirectly consequent to fetal growth restriction due to preeclampsia and not directly to the latter. One hypothesis relates to an imbalance in angiogenic factors, and consequent impaired angiogenesis, potentially having a significant role, contributing to the abnormal structure and distribution of the distal microvasculature in the lungs of infants with BPD $[29,30]$.

Looking at preeclampsia, the EPIPAGE-2 Cohort Study [31] showed how placental-mediated pregnancy complications with fetal consequences are associated with moderate to severe BPD in very preterm infants, but isolated maternal hypertensive disorders are not. This suggests again how fetal growth restriction could be the principal mechanism involved in BPD development.

Some authors have suggested that chorioamnionitis is associated with BPD, as it would give rise to higher concentrations of proinflammatory cytokines in the amniotic fluid [32]. This would mean that the pathogenesis of BPD begins already in utero, in the choriodecidua, and untargeted metabolomic profiling of the amniotic fluid would seem to confirm such a hypothesis $[33,34]$. The role of chorioamnionitis in the onset of BPD is still debated, however [35].

Morrow et al. [36] evidenced how maternal smoking during pregnancy increased the odds of having an infant with moderate or severe BPD by 2.02-fold, suggesting increased inflammatory cytokine production, altered placental function, or direct impact on lung development, which disrupts lung structure and function as possible involved mechanisms [37,38]. Maternal smoking results also related to a higher risk of late respiratory disease in former preterm babies [36], defined as any of the following events occurred over the first 2 years of life: one or more respiratory hospitalizations; use of inhaled steroids, inhaled bronchodilators, and/or diuretics; and a physician's diagnosis of asthma, reactive airway disease, or a BPD exacerbation.

Multiple pregnancy has been excluded as a risk factor for BPD [39,40], but a high concordance between twins has been described [41].

Among the extremely low birth weight (ELBW) newborns, some cases may be similar and have similar histories, but not all of them will develop BPD. This would suggest a genetic predisposition, a possibility supported by evidence of monochorial twins having a significantly higher concordance in the incidence of BPD than bichorial twins: up to $79 \%$ of this variance has been attributed to genetics [41,42]. Such genetic factors have been investigated mainly in gene ablation studies, in relation to lung branching morphogenesis [43,44], in models of lung disease [18], and-more recently-in genome-wide association studies and exome sequencing on preterm-born infants. Multiple genes have been examined and proposed as BPD risk factors, but no clear genetic target has been identified so far $[45,46]$. A recent wide exome sequencing (WES) study [47] has been able to identify some gene variants that could be suitable to be evaluated as BPD predisposing factors, but more importantly, all the associated pathways could become future targets for therapy and prevention of BPD.

\section{Demographic Risk Factors at Birth}

Extreme prematurity and extremely low birth weight, associated with a small and underdeveloped lung, are obvious risk factors for BPD. 
In addition, the mode of delivery seems to have been identified as related with a different incidence of BPD, with C-sections seeming to be related to a reduced rate of BPD [36]; a possible explication is the influence of vaginal flora on the microbioma [48], but this relationship is not always confirmed [49] and it was not protective against late respiratory disease [36].

Male sex also seems to correlate with a higher risk of BPD than in females [50,51]. Some animal studies have explained this with a higher level of inflammation, and a more severe loss of alveolarization and angiogenesis in males [52].

Ethnicity seems to influence the risk of developing BPD too, with black race carrying a lower risk of BPD but a higher risk of persistent respiratory morbidity [53].

\section{Postnatal Risk Factors}

A particularly fascinating field of investigation concerns how lung tissue healing processes may mimic intrinsic ontogenic phases to reproduce the physiological machinery. Having only immature or no antioxidant defenses [54] exposes the preterm newborn to BPD because they are likely to need oxygen supplementation; this prompts an excessive production of cytotoxic reactive oxygen metabolites, which overcome the antioxidant system [55].

Hyperoxia is the best-known and most often-studied postnatal risk factor for BPD. Its pathogenesis includes epithelial and endothelial cell death, inflammation, impaired mitochondrial function [56], and reduced numbers of resident lung and systemic progenitor cells $[57,58]$.

Mechanical ventilation and volutrauma or endotrauma have been identified among the main causes of BPD, as a result of bronchiolar hyperinflation and injury [59] leading to the activation of inflammatory signaling in resident lung cells [60], inducing the recruitment of inflammatory cells [61], and altering the pathways involved in alveolarization [62]. This association has prompted neonatologists to change their ventilation strategies, starting already in the delivery room. Lower tidal volumes and less invasive ventilation techniques are now used to help protect the infant's lung.

Another suggested pathway involves late surfactant deficiencies, but recent studies testing the late administration of surfactant have shown little or no benefit [63]. This might be because multiple mechanisms are implicated, such as a decreased de novo surfactant production, an increased degradation of intra-alveolar large aggregate surfactant, a loss of alveolar surfactant secondary to phagocytosis, and a diminished recycling of surfactant phospholipids [64].

Sepsis is another factor associated with a higher risk of BPD, especially in infants with candidemia [65], an infection that naturally activates the inflammatory cascade with a consequent production of pro-inflammatory cytokines, the migration of PMNs, and changes in vascular permeability, all of which promptly cause alveolar damage, and long-term alterations as well. It is important to emphasize that a common, and often underestimated infection like Staphylococcus epidermidis also induces pro-inflammatory responses in human alveolar epithelial cells [66].

This risk of BPD is amplified by a symptomatic patent ductus arteriosus (PDA) [67], even though the pathogenic mechanism behind this association is still unclear.

The microbiota is an important emerging field of interest; the fetal lung has probably its own microbiota since fetal life, seen that placenta and amniotic fluid harbor their own microbiota [68]. Lung microbiota, influencing the homeostatic control and development of immune system [69], could influence also the inflammatory and tissue repair responses to pathogenetic insults. Recently, an alteration of lung microbiota, specifically a reduction in its diversity at birth, seems related with BPD development $[70,71]$. Another possible mechanism through which microbioma can influence lung development is microbial metabolite production altering inflammatory response [72,73].

Extrauterine growth restriction (EUGR) correlates with a higher risk of BPD too [74,75], and this association is theoretically attributable to a reduced lung growth as a result of a reduction in body growth and its mediators. Postnatal growth restriction is quite common in preterm infants; its presence and its combination with hyperoxia result in decreased expression of key modulators of angiogenesis and vascular tone including VEGF, VEGF receptor 2, HIF1 $\alpha$, HIF2 $\alpha$, eNOS and NOS metabolites [74], 
again suggesting the importance of the vascular hypothesis in BPD development, but many other mechanisms could be involved [76]. To ensure a good nutritional intake will so result in a reduced risk of BPD, but also improve neurodevelopment [77].

All these risk factors take effect by altering various pathways that contribute in some way to the development of BPD.

\section{Cellular Modifications}

One of the intriguing aspects of BPD concerns the role of inflammatory cells in its pathobiology. Macrophage polarization causes a paradoxical derecruitment of M1 vis-à-vis M2 cells. M1 macrophages have proinflammatory functions, while M2 macrophages are involved in healing and repair pathways. Macrophage phenotype seems to be associated with disease severity in preterm infants with BPD [78,79]. Both the choriodecidua and lung response appear to have a part to play as well, judging from findings in tracheal aspirates from preterm newborns [80]. Neutrophils act as host defense cells, reacting to injury caused by oxidative species, cytokines or elastases [81]. They have also been studied more recently for their role in tissue repair through defensins and elastases: such an action in the lung of mucosa-protecting effect of neutrophils is now being investigated [82].

Another area of investigation is the system of pulmonary neuroendocrine cells (PNECs): changes in the number of these cells, and in their peptide levels, have been reported in infants with BPD [83,84], and in rats exposed to hyperoxia [85]. The role of PNECs, and of drugs acting on their serotonin production, deserves further study. Higher levels of bombesin-like peptide, and of calcitonin- and serotonin-immunoreactive PNECs have been reported in infants dying of BPD [83].

One working hypothesis is that exhaustion or dysfunction of the lung's resident stem/progenitor cells contributes to lung growth impairment in BPD, and to the immature lung's inability to repair itself [86-88].

\section{Growth Factor Alterations}

All the above-mentioned (cellular and mediator) mechanisms have to do with the inflammasome, which is crucial to the development of BPD. There have been several reports of proinflammatory and chemotactic factors being detected in higher or lower concentrations in infants developing BPD $[89,90]$. In particular, certain cytokines (IL-6, IL-8 and GM-CSF) seem to be directly involved in early lung injury evolving into BPD. Transforming growth factor $\beta$ (TGF- $\beta$ ) is implicated in elastogenesis and alterations in this process due to an inflammatory stimulus have an antiproliferative effect on alveolarization [91,92]. Leroy et al. [93] demonstrated that systemic inflammation occurs early in the neonatal period in infants with BPD, before any clinical symptoms become apparent.

Growth factors are heavily implicated in the pathogenesis of BPD. In particular, lower serum levels of insulin-like growth factor-1 (IGF-1) relate to the onset of BPD [94-97], however high the tissue levels of IGF-1 and its receptor IGF-1R might be in the peribronchial and perialveolar mesenchyme $[95,98,99]$. IGF-1 could be said to behave like a hormone in the general circulation, but like a cytokine at local level. Systemic IGF-1 is a growth stimulant and growth marker. One hypothesis for its link with BPD is that IGF-1 is a vascular endothelial growth factor (VEGF) stimulator [100], with a possible involvement in lung angiogenesis. Another possible mechanism is that low levels of this hormone are related to extrauterine growth restriction (EUGR), which is a risk factor for BPD. On the other hand, IGF-1 is locally involved in the lung injury/repair process, enhancing the local proliferation of human fetal lung fibroblasts, and stimulating collagen production—both of which are part of the aberrant lung repair process.

Past and present studies are revealing the crucial role of lung angiogenesis: as it actively promotes alveolar growth, an altered angiogenesis (i.e., high levels of endostatin or bombesin-like peptides) probably plays a part in the pathogenesis of BPD as well [101-103]. Researchers have identified a suppressed vascular growth in the early stages of BPD, and an excessive, dysmorphic (probably compensatory) growth in later stages, which would pave the way to pulmonary hypertension [104,105]. 
VEGF is one of the main elements involved in angiogenesis, and consequently, in lung development. Its inhibition seems to impair angiogenesis and distal airspace growth, and to cause pulmonary hypertension in neonatal and infant rats [106]. The levels of this growth factor are distinctly elevated in airway aspirates obtained in the first days of postnatal life from preterm infants who later develop BPD [107], but blood levels of VEGF seem to be lower than normal in infants developing BPD [108].

All the above-described potential mechanisms go to show that BPD is not really a single disorder, but a set of disorders (all of which involve a disrupted alveolar and vascular growth), and different factors may contribute to its development in different patients at risk. All these factors contributing to a perturbed lung development may also follow different paths and carry a different weight in the progression of BPD in different individuals.

\section{Animal Models and Morphometric Methods}

Various experimental animal models of BPD have been developed in an effort to improve our understanding of its pathogenesis and assess possible therapies. These models have included: postnatal exposure to hyperoxia of term-born mice [109], and rats [110], and preterm or term-born rabbits [111]; and chronic artificial ventilation of preterm lambs [112], and preterm baboons [113]. As stated by Nardiello et al. [114], these efforts have pointed to an increasing need for a standardized model. In experimental studies addressing strategies for the prevention and treatment of BPD, it is pivotal to use reliable and unbiased morphometric methods to quantify alveolarization. Radial alveolar counts (RAC) and mean linear intercepts (Lm) are frequently adopted as surrogates for alveolar size and alveolar number, but these methods are not completely unbiased because they are calculated in surfaces and not in three-dimensional probes. That is why the latest standards for quantitatively assessing lung structure (such as those of the American Thoracic Society/European Respiratory Society) stress the importance of using unbiased stereological methods [115]. The main stereological parameters for assessing alveolarization are: total volume of alveolar air spaces; total number of alveoli; mean alveolar volume; total volume and surface area of alveolar septa; and mean alveolar septal thickness [116-118]. Recently, automatically derived parameters have been evaluated in comparison with stereological analysis, demonstrating a comparable efficiency in detecting changes in alveolarization [119], with a fractal approach that may be fit to this automatic analysis [118].

\section{Prevention and Management}

Ultimately, the most effective strategy for preventing BPD is to avoid extreme preterm birth [2]. Where this is impossible, the current approach to BPD includes numerous prevention strategies, albeit of limited efficacy in this respiratory disease. Some routinely used therapies are listed below (Table 1). 
Table 1. BPD prevention strategies.

\begin{tabular}{|c|c|}
\hline & BPD Prevention Methods \\
\hline Antenatal glucocorticoids & $\begin{array}{l}\text { Given to women between } 23 \text { and } 34 \text { WG } \\
\text { Less respiratory distress syndrome } \\
\text { Shorter periods of mechanical ventilation and oxygen supplementation [120] }\end{array}$ \\
\hline Surfactant & Reduces the need for mechanical ventilation and oxygen dependence [121] \\
\hline LISA technique [122] & Reduces the need for mechanical ventilation $[123,124]$ \\
\hline $\begin{array}{l}\text { Protective } \\
\text { ventilation }\end{array}$ & $\begin{array}{l}\text { Low tidal volumes } \\
\text { Early weaning from mechanical ventilation } \\
\text { Early CPAP and noninvasive ventilation }\end{array}$ \\
\hline $\begin{array}{c}\text { Targeted } \mathrm{O}_{2} \\
\text { saturation }\end{array}$ & Reducesoxidative damage [125] \\
\hline Early therapy with caffeine & $\begin{array}{l}\text { Shorter time on ventilatory support [126] } \\
\text { Better lung function [127,128] } \\
\text { Modulates angiogenic gene expression early in lung development [129] }\end{array}$ \\
\hline Vitamin A & $\begin{array}{l}\text { Has a role in lung maturation and repair } \\
\text { Reduces the development of BPD at } 36 \text { weeks PMA, but has no effect on } \\
\text { long-term respiratory morbidity [130-135] }\end{array}$ \\
\hline $\begin{array}{l}\text { Postnatal } \\
\text { infection control }\end{array}$ & Reduces inflammatory mediators and the need for mechanical ventilation \\
\hline $\begin{array}{l}\text { Hemodynamically significant } \\
\text { PDA treatment }\end{array}$ & Reduces pulmonary overflow, and this limits the need for ventilation [136] \\
\hline Fluid restriction & $\begin{array}{l}\text { Prevents pulmonary overflow and consequent lung edema } \\
\text { Reduces the incidence of PDA [137] }\end{array}$ \\
\hline Azithromycin prophylaxis & In newborns colonized with Urea plasma [138] \\
\hline Nutrition & $\begin{array}{l}\text { Adequate enteral supplement of nutrients [139] } \\
\text { Possibly with mother's own milk [140,141] } \\
\text { To ensure a good weight gain [142] } \\
\text { L-citrulline in particular seems to correlate with a lower incidence of } \\
\text { Pulmonary hypertension }[143,144] \text { (an interesting trial [NCT03542812] is } \\
\text { ongoing) }\end{array}$ \\
\hline $\begin{array}{l}\text { Postnatal systemic } \\
\text { glucocorticoids }\end{array}$ & $\begin{array}{l}\text { Reduce inflammation, vascular permeability and lung edema } \\
\text { Their short- and long-term adverse effects suggest caution in their routine } \\
\text { use for preventing BPD [145] }\end{array}$ \\
\hline
\end{tabular}

Together, these measures have reduced the BPD-related mortality rates among preterm infants, but not the incidence of BPD [3] (because of the rising numbers of infants at risk of this disease). Hence, the ongoing need to seek innovative approaches and more effective therapies for BPD.

\section{Long-term Pulmonary Outcome}

Physiologically, lung function tends to increase gradually throughout childhood and adolescence, reaching a plateau at around 23-25 years of age [146]. It is now clear that people entering adulthood with a lower than normal lung function are at a higher risk of developing chronic obstructive pulmonary disease (COPD) in later life. That is why it is so important to contain early neonatal lung injury [22,147]. BPD and prematurity are clear examples of how an insult occurring in the perinatal period can be associated with health issues that persist into adult age [147,148].

Even if we lack the ideal technology for assessing lung function in infants, several cross-sectional studies have studied BPD survivors of school age and older, documenting their airway obstruction [149-151]. An impaired lung function has been identified in both "old" and "new" BPD survivors, and it is associated with more respiratory symptoms and abnormal chest imaging findings [152]. In addition, a deterioration 
of lung function during childhood and adolescence has been described in longitudinal studies of preterm and BPD survivors [153-155].

Our group recently published the results of the "Padova BPD study" [156] begun in 1991 (at the start of the "surfactant era") to monitor lung function in BPD survivors longitudinally from birth to early adulthood. This study showed that significant airway obstruction in infancy persisted at 24 years of age, associated with a failure to achieve an optimal peak lung function in the adult. Being based on data from birth onwards, these findings support the concept of BPD as the earliest-onset and longest-lasting obstructive pulmonary disease in humans, which could predispose to COPD in adulthood $[7,156]$.

COPD is commonly considered a smoking-related condition in so-called "susceptible" smokers, but about one in three COPD patients have never smoked. Nowadays, COPD is seen as a syndrome with different phenotypes and natural histories. Factors taking effect at different times early in life, such as abnormal lung growth, maternal smoking, childhood asthma, and early respiratory infections, may impair lung function and raise the risk of COPD, and strategies to avoid them can help prevent its development in adult life [157].

A relevant question is whether the long-term pulmonary consequences of prematurity and BPD depend essentially on stable structural damage, or also reflect an ongoing, active airway disease [158]. For the time being, there are no pathological data available to shed light on the characteristics of BPD survivors' lung tissue beyond infancy. In a recent case series of histopathological findings in bronchial biopsies from adolescent survivors of BPD, the authors reported finding lymphocytic infiltrates and signs of immature neo-angiogenesis, pointing to an ongoing active inflammatory process in their airways [159].

\section{BPD Treatment: Prospects and Needs}

\subsection{BPD Biomarkers}

All promising treatments have to be tested, then used only for patients likely to benefit from them. This means that we need to identify patients likely to develop BPD as early as possible. Then, we need to establish which pathogenic mechanisms are the main culprits in the single infant in order to provide the most appropriate treatment in each case.

A reliable biomarker would have to be detectable in the early phase of the disease, and thus, enable prompt intervention to prevent or minimize its detrimental effects. The cellular and blood/fluid markers tested to date do not fit the bill because they have shown a low predictive value, adding minimal power to clinical variables alone [160].

The so-called "-omic" techniques have clearly brought advances in the detection of early biomarkers of BPD, and several promising studies have been published [161,162]. These technologies have yet to pinpoint a gold-standard biomarker for use in the routine clinical care of infants at risk of BPD however [163]. Using proteomic screening in preterm infants, one study recently found a validated set of proteins (SIGLEC-14, BCAM and ANGPTL3) capable of identifying BPD soon after birth and pointing to key processes in the disease's subsequent development [164]. Another study applied metabolomics to the analysis of amniotic fluid, and the authors suggested that this approach might be useful for predicting BPD [33]. Such -omic techniques have the potential to uncover new developmental pathways that may help us to find new targets for therapy.

\subsection{Other BPD Predictors}

A web-based BPD estimator was recently developed by NICHD to identify infants at risk of BPD who may benefit from postnatal steroids [50,165].

Though it is not a biomarker, lung MRI has recently revealed a good capacity for predicting short-term outcomes in the setting of BPD [166]. Lung ultrasound has also proved capable of predicting the onset of BPD [167]. 
In future, these tools (like biomarkers) can probably help pinpoint patients at higher risk of BPD, and also, enable us to improve on its definition and the scoring of its severity.

\section{New Horizons}

\subsection{Corticosteroids}

We have known for years that corticosteroids are effective in improving respiratory function in preterm infants, but these drugs have recently been put to a new use [168]. Their systemic use has been considerably reduced in the last decade, owing to fears over side effects, and especially possible neurological consequences, such as a higher risk of cerebral palsy [169]. Recent evidence has tended to debunk such worries and encourage a cautious, more targeted use of systemic steroids, though a large-scale RCT will be needed to clarify the best posology [170]. Another reason for a renewed enthusiasm for steroids lies in results obtained recently with their prophylactic use [171,172].

Another approach that has been explored involves the intratracheal administration of corticosteroids (in an effort to avoid their unwelcome effects). A recent paper reported encouraging results of administering intratracheal budesonide mixed with surfactant [173]. At a time when we may still have our doubts about the use of systemic corticosteroids, this targeted therapy could prove a promising, readily accepted and effective strategy [174]. McEvoy et al. [175] evaluated the optimal safe dose of this treatment, showing a lung-targeted anti-inflammatory effect with a tenth of the previously used dose, with minimal systemic metabolic effects, and evidenced a systemic passage of the treatment, slightly reducing the enthusiasm about targeted therapy.

With the same goal in mind, aerosolized steroids have been the object of numerous studies. In one recent report, early use (within $24 \mathrm{~h}$ ) of inhaled budesonide in extremely preterm newborns was found associated with a lower incidence of BPD. At two-year follow-up, the study found no differences in terms of neurodevelopmental disability, but the mortality was higher in a steroid-treated group [176-178]. However, the dose of inhaled corticosteroids used in this study was very high.

\subsection{Growth Factors}

Looking at the pathogenesis of BPD, growth factors (or their agonists and antagonists) would seem to have therapeutic potential. When the use of IGF-1 supplementation to prevent retinopathy of prematurity was examined, it achieved the encouraging secondary outcome of a reduction in the incidence and severity of BPD [96]. This led to the suggestion of a possible new therapeutic approach that is currently the object of a study by Takeda-Shire [179].

As for the involvement of angiogenesis in the development of BPD, the antenatal or postnatal inhibition of VEGF with a monoclonal antibody against soluble fms-like tyrosine kinase (sFlt-1) prompted an improvement in lung structure in an animal model of BPD [180].

The already cited wide exome sequencing study [47] could offer some new perspectives in this field, unraveling future new pathways to evaluate and target.

\subsection{Mesenchymal Stem/Stromal Cells and Extracellular Vesicles}

Several studies on BPD found a reduction in the population of resident stem cells in patients' lungs [86-88]. This prompted the suggestion that such a phenomenon could have a role in the pathogenesis of BPD, and that replacing this cell population might help reverse the course of the disease. Mesenchymal stem/stromal cells (MSCs) have been investigated as a potential tool for preventing and treating many lung diseases. MSCs were originally described as stem cells, but it was later recognized that data to support such a functional designation are still lacking, so the term "stromal" was recommended by the International Society for Cellular Therapy [181]. MSCs are plastic-adherent cells with a multipotent differentiation capacity in vitro. They can be isolated from a variety of tissues, including bone marrow, fat, cord blood and tissue, and placenta [182]. They can modulate immune response, promote angiogenesis, and enhance regeneration and repair to protect tissues against a 
variety of injuries. These properties make MSCs an attractive therapeutic tool in regenerative medicine, particularly in pediatric diseases $[183,184]$.

Kourembanas' group [185] was the first to demonstrate the beneficial effects of intravenous MSCs or MSC-conditioned medium (CM) in an animal model of hyperoxia-induced BPD. Their promising results were confirmed by other investigators using intravenous, intratracheal [186-194] and, more recently, intraperitoneal [195] and intranasal [196] modes of administration. These treatments lowered the levels of inflammatory mediators like IL-6 and TNF- $\alpha$ [197], and the expression of angiotensin II, angiotensin II type 1 receptor, and angiotensin-converting enzyme [198], which are involved in the development of BPD. MSCs also improved alveolar structure and angiogenesis, attenuating lung fibrosis and inflammation, and increasing exercise capacity in animal models of BPD [186,187,190].

Intriguingly, the intratracheal administration of MSCs derived from human umbilical cord blood was found to attenuate both lung and brain injuries in rat pups exposed to hyperoxia [199], suggesting that local administration can have systemic effects. O'Reilly et al. [200] recently described how multiple doses of MSCs improved BPD-like lung injury, both early on and at a later stage of the disease.

Only two translational trials have been published to date on the use of MSCs for treating BPD in humans [201,202]. In a phase I dose-escalation study, Chang et al. [201] tested the safety and feasibility of intratracheal MSCs in nine preterm infants at high risk of BPD. The treatment was well tolerated and without any serious adverse effects. As a secondary endpoint, this study also reported some preliminary evidence of the treatment's efficacy, since the IL-6, IL-8, MMP-9, TNF- $\alpha$ and TGF- $\beta 1$ levels in tracheal aspirates were lower after the treatment, and MSC recipients seemed to have less severe BPD. It should be noted, however, that the time course of inflammatory cytokine production in BPD is not known, and the clinical comparison was drawn with a historical case-matched group. A two-year follow-up study confirmed the lack of any long-term side effects in the babies treated with MSCs [203]. Powell et al. [202] performed a similar phase I dose-escalation trial on the safety and feasibility of intratracheal MSCs in twelve preterm infants at high risk of BPD. Here again, the treatment was well tolerated and appeared to be safe and feasible. This study did not include a control group, however, and the authors voiced the need for a larger, blinded RCT.

Similar beneficial effects were seen after administering other types of cell, including cells derived from human amniotic fluid [204-206], and epithelial progenitor cells. The safety, tolerance and feasibility of the intravenous administration of human amnion epithelial cells (hAECs) were recently tested by Lim et al. [207] on six infants with BPD, finding no adverse events in the short-term, or at two years of age [208].

These pioneering studies have generated great interest in cell therapy for the prevention of BPD. Table 2 provides a list of similar recent and ongoing studies.

MSCs were initially believed to differentiate and repopulate injured sites with tissue-specific cell phenotypes, but it soon became evident that the therapeutic effects observed were mediated by paracrine signals regulating immune response, counteracting apoptosis, limiting fibrogenesis, stimulating endogenous stem cells, and thus, resulting in tissue repair [209,210]. In the last decade, accumulating evidence has shown that such signals are conveyed mainly by various membrane vesicles, including exosomes and microvesicles, which are collectively known as "extracellular vesicles" (EVs) [211-213]. EVs are complex biological machines secreted by all cell types. They range from 0.03 to 1 micron in size. They are distinguished mainly by their biogenesis, since they exhibit overlapping physical and chemical characteristics. EVs can affect both the metabolism and the phenotype of target cells by delivering their cargo of proteins, miRNA, mRNA, DNA, and even mitochondria. The immune modulating and pro-regenerative effects of MSC-derived EVs have been confirmed both in vitro [214-216] and in several animal models of disease [217-219], but the mechanism of action of EVs remains largely a mystery. Part of their therapeutic effect seems to be mediated by tumor necrosis factor alpha-stimulated gene-6 (TSG-6) [220] and VEGF [221]. On the other hand, as Willis et al. [222] noted, EV treatment results in pleiotropic effects on genes associated with hyperoxia-induced inflammation and immune responses. One such effect is to modulate the macrophage phenotype fulcrum, suppressing 
the proinflammatory "M1-like" activation and switching to an anti-inflammatory "M2-like" state. This futuristic therapy has aroused great interest because of the growing evidence of EVs isolated from MSC-conditioned medium having a therapeutic effect in experimental models of BPD [219,222-225], whether they are administered intravenously or intratracheally. The intraperitoneal administration of EVs was recently considered in an animal model, again with encouraging results [195]. Since EVs are not living cells, they should carry little risk of tumorigenesis or ectopic colonization. In addition, they do not react differentially and unpredictably (like MSCs) to different environments, so they should be more consistent as a therapeutic tool. EVs also have the advantage over MSCs of being cheaper and easier to manage (i.e., to isolate, store and administer) [224]. Our knowledge of their biology and biodistribution, and of the interaction between EVs and target cells is still insufficient, however. Clinical experience is limited to a few trials on the use of EVs derived from dendritic cells in adoptive immune therapies for cancer [226,227], and a single case treated with MSC-derived EVs for steroid-resistant GVHD [228]. As we write, one trial (NCT03857841) is actively recruiting preterm newborns delivered at less than $27 \mathrm{WG}$ at high risk of BPD for the purpose of testing the safety and feasibility of intravenous infusions of bone marrow MSC-derived EVs (UNEX-42). Clearly, before any clinical implementation of these interesting nanoparticles in the treatment of BPD, we need to gain a better understanding of their mode of action, assess their safety, and confirm their efficacy. An even more futuristic approach is the engineering of extracellular vesicles; this appears as a new frontier in order to treat inflammatory diseases with more targeted and specific molecules $[229,230]$.

Table 2. Ongoing trials with stem cells for BPD.

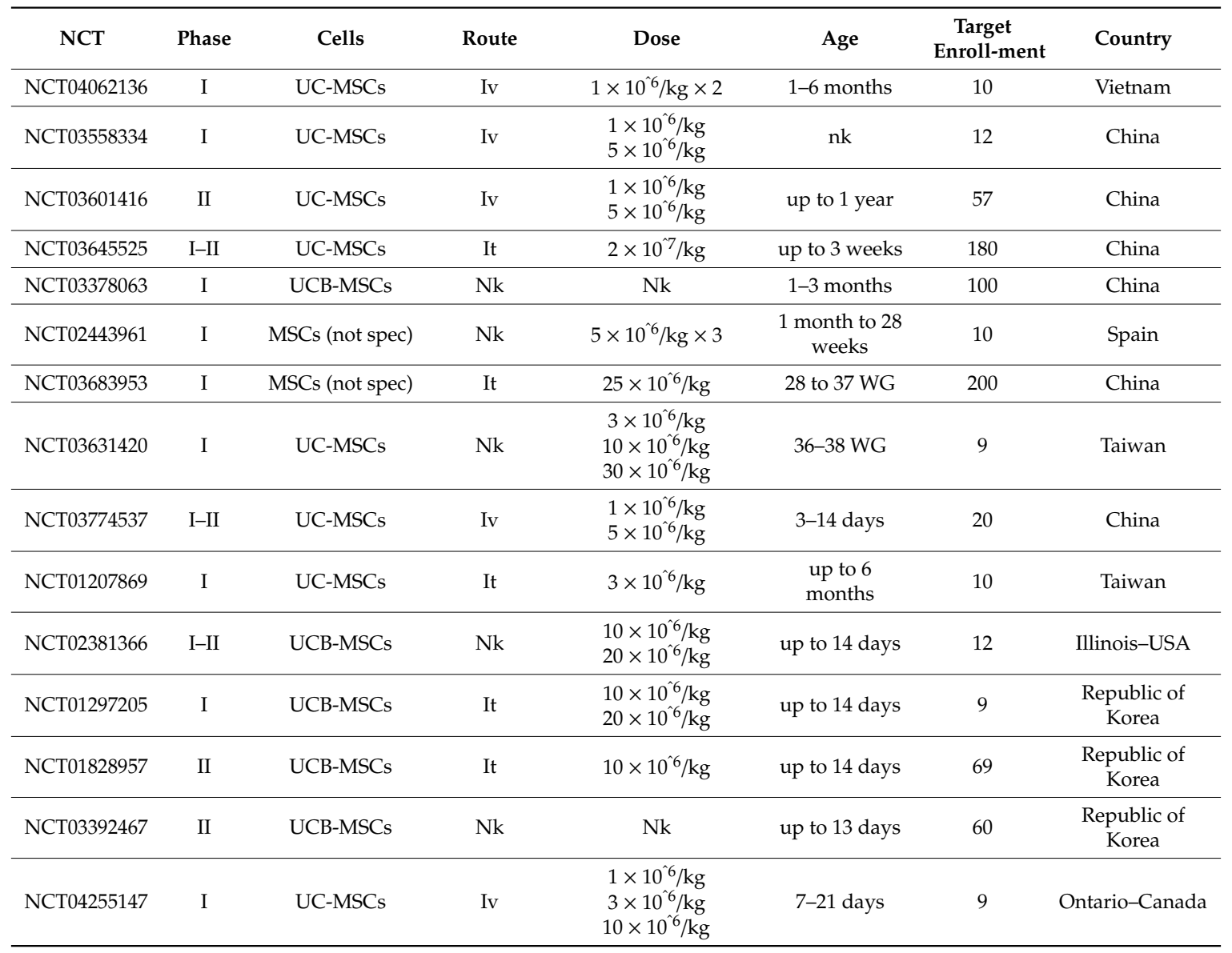

Abbreviations: UC: umbilical cord; UCB: umbilical cord blood; MSCs: mesenchymal stem cells; iv: intravenous; it: intratracheal; nk: not known; WG: weeks of gestation. 
Research performed on clinicaltrials.gov, updated at 5 February 2020, some of these studies preview related follow up studies.

\section{Future Needs}

An important challenge for the future is to identify BPD biomarkers that help us to predict the need for treatment. Then, we can use these novel therapeutic strategies only in those infants who really need them. Genomics, transcriptomics, proteomics, metabolomics, nutritional factors, and maternal antenatal drugs are all worth considering in BPD research and the international debate on this disorder.

The treatments discussed in this paper are at various stages of clinical implementation. "Topical" steroids are already being used in large-scale clinical studies seeking to definitively confirm the very encouraging preliminary results obtained, and hopefully, rule out any associated increase in mortality [173]. This would seem to be the most obvious next step forward in the management of BPD. IGF-1 therapy is already being applied in clinical settings, while we await the results of a large multicenter study to confirm the early enthusiasm for its use to prevent BPD.

Two of the most revolutionary treatments, MSCs and EVs, are still in the preclinical and experimental stages, which must be completed before any translational use can be attempted [231]. The results obtained so far have been remarkable, but they have the important technical limitation of the small size of the animal model involved.

We can logically expect the use of EVs to be safe (as they are an element contained in MSC-based therapies), but this issue has yet to be fully explored in a phase 1 human study. The most appropriate mode (intravenous or intratracheal) and timing of administration, and the optimal dosage also need to be established. A standardized method for generating and harvesting EVs will also be needed to obtain a product for use in human translational applications [232].

In conclusion, BPD experts and caregivers are looking forward to seeing some really revolutionary advances in the treatment of a disease that is well known, and for which there are numerous evidence-based options to help in its prevention and improve its symptoms, but no definitive treatment to date.

The development of EV-based therapeutics is considered the most promising next-generation approach to preterm infants at risk of BPD. Such treatment may considerably improve the shortand long-term lung development of affected patients, completely changing the natural history of this disease.

Author Contributions: L.B., P.Z., A.P., M.M. and E.B. contributed equally to the manuscript. Writing-original: L.B., P.Z., A.P., Writing - review and editing: M.M., G.P., Supervision: E.B. All authors have read and agreed to the published version of the manuscript.

Funding: This research received no external funding.

Conflicts of Interest: The authors declare no conflicts of interest.

\section{References}

1. Northway, W.H.; Rosan, R.C.; Porter, D.Y. Pulmonary disease following respirator therapy of hyaline-membrane disease. N. Engl. J. Med. 1967, 276, 357-368. [CrossRef] [PubMed]

2. Abman, S.H.; Bancalari, E.; Jobe, A. The evolution of bronchopulmonary dysplasia after 50 years. Am. J. Respir. Crit. Care Med. 2017, 195, 421-424. [CrossRef]

3. Stoll, B.J.; Hansen, N.I.; Bell, E.F.; Walsh, M.C.; Carlo, W.A.; Shankaran, S.; Laptook, A.R.; Sánchez, P.J.; Van Meurs, K.P.; Wyckoff, M.; et al. Trends in care practices, morbidity, and mortality of extremely preterm Neonates, 1993-2012. JAMA J. Am. Med. Assoc. 2015, 314, 1039-1051. [CrossRef] [PubMed]

4. Devries, L.B.; Heyne, R.J.; Ramaciotti, C.; Brown, L.S.; Jaleel, M.A.; Kapadia, V.S.; Burchfield, P.J.; Brion, L.P. Mortality among infants with evolving bronchopulmonary dysplasia increases with major surgery and with pulmonary hypertension. J. Perinatol. 2017, 37, 1043-1046. [CrossRef] 
5. Lagatta, J.M.; Hysinger, E.B.; Zaniletti, I.; Wymore, E.M.; Vyas-Read, S.; Yallapragada, S.; Nelin, L.D.; Truog, W.E.; Padula, M.A.; Porta, N.F.M.; et al. The impact of pulmonary hypertension in preterm infants with severe bronchopulmonary dysplasia through 1 year. J. Pediatr. 2018. [CrossRef] [PubMed]

6. Abman, S.H.; Collaco, J.M.; Shepherd, E.G.; Keszler, M.; Cuevas-Guaman, M.; Welty, S.E.; Truog, W.E.; McGrath-Morrow, S.A.; Moore, P.E.; Rhein, L.M.; et al. Interdisciplinary Care of Children with Severe Bronchopulmonary Dysplasia. J. Pediatr. 2017, 181, 12-28. [CrossRef]

7. Carraro, S.; Filippone, M.; Da Dalt, L.; Ferraro, V.; Maretti, M.; Bressan, S.; El Mazloum, D.; Baraldi, E. Bronchopulmonary dysplasia: The earliest and perhaps the longest lasting obstructive lung disease in humans. Early Hum. Dev. 2013, 89, S3-S5. [CrossRef]

8. Crump, C.; Sundquist, J.; Winkleby, M.A.; Sundquist, K. Gestational age at birth and mortality from infancy into mid-adulthood: A national cohort study. Lancet Child Adolesc. Health 2019, 3, 408-417. [CrossRef]

9. Jobe, A.H.; Bancalari, E. Bronchopulmonary dysplasia. In Proceedings of the American Journal of Respiratory and Critical Care Medicine; American Thoracic Society: New York, NY, USA, 2001; Volume 163, pp. 1723-1729. [CrossRef]

10. Walsh, M.C.; Wilson-Costello, D.; Zadell, A.; Newman, N.; Fanaroff, A. Safety, reliability, and validity of a physiologic definition of bronchopulmonary dysplasia. J. Perinatol. 2003, 23, 451-456. [CrossRef]

11. Higgins, R.D.; Jobe, A.H.; Koso-Thomas, M.; Bancalari, E.; Viscardi, R.M.; Hartert, T.V.; Ryan, R.M.; Kallapur, S.G.; Steinhorn, R.H.; Konduri, G.G.; et al. Bronchopulmonary dysplasia: Executive summary of a workshop. J. Pediatr. 2018, 197, 300-308. [CrossRef]

12. Ibrahim, J.; Bhandari, V. The definition of bronchopulmonary dysplasia: An evolving dilemma. Pediatr. Res. 2018. [CrossRef] [PubMed]

13. Steinhorn, R.; Davis, J.M.; Göpel, W.; Jobe, A.; Abman, S.; Laughon, M.; Bancalari, E.; Aschner, J.; Ballard, R.; Greenough, A.; et al. Chronic pulmonary insufficiency of prematurity: Developing optimal endpoints for drug development. J. Pediatr. 2017, 191, e1-21. [CrossRef] [PubMed]

14. Isayama, T.; Lee, S.K.; Yang, J.; Lee, D.; Daspal, S.; Dunn, M.; Shah, P.S. Revisiting the definition of bronchopulmonary dysplasia effect of changing panoply of respiratory support for preterm neonates. JAMA Pediatr. 2017, 171, 271-279. [CrossRef] [PubMed]

15. Jensen, E.A.; Dysart, K.; Gantz, M.G.; McDonald, S.; Bamat, N.A.; Keszler, M.; Kirpalani, H.; Laughon, M.M.; Poindexter, B.B.; Duncan, A.F.; et al. The diagnosis of bronchopulmonary dysplasia in very preterm infants an evidence-based approach. Am. J. Respir. Crit. Care Med. 2019, 200, 751-759. [CrossRef]

16. Thébaud, B.; Goss, K.N.; Laughon, M.; Whitsett, J.A.; Abman, S.H.; Steinhorn, R.H.; Aschner, J.L.; Davis, P.G.; McGrath-Morrow, S.A.; Soll, R.F.; et al. Bronchopulmonary dysplasia. Nat. Rev. Dis. Prim. 2019, 5, 78. [CrossRef]

17. Coalson, J.J. Pathology of bronchopulmonary dysplasia. Semin. Perinatol. 2006, 30, 179-184. [CrossRef]

18. Alvira, C.M.; Morty, R.E. Can we understand the pathobiology of bronchopulmonary dysplasia? J. Pediatr. 2017, 190, 27-37. [CrossRef]

19. Galambos, C.; Sims-Lucas, S.; Abman, S.H. Histologic evidence of intrapulmonary anastomoses by three-dimensional reconstruction in severe bronchopulmonary dysplasia. Ann. Am. Thorac. Soc. 2013, 10, 474-481. [CrossRef] [PubMed]

20. Surate Solaligue, D.E.; Rodríguez-Castillo, J.A.; Ahlbrecht, K.; Morty, R.E. Recent advances in our understanding of the mechanisms of late lung development and bronchopulmonary dysplasia. Am. J. Physiol. Lung Cell. Mol. Physiol. 2017, 313, L1101-L1153. [CrossRef]

21. Allen, M.C.; Donohue, P.K.; Dusman, A.E. The limit of viability-neonatal outcome of infants born at 22 to 25 weeks' gestation. N. Engl. J. Med. 1993, 329, 1597-1601. [CrossRef]

22. Baraldi, E.; Filippone, M. Chronic lung disease after premature birth. N. Engl. J. Med. 2007, 357, $1946-1955$. [CrossRef] [PubMed]

23. Gortner, L.; Misselwitz, B.; Milligan, D.; Zeitlin, J.; Kollée, L.; Boerch, K.; Agostino, R.; Van Reempts, P.; Chabernaud, J.L.; Bréart, G.; et al. Rates of bronchopulmonary dysplasia in very preterm neonates in Europe: Results from the MOSAIC cohort. Neonatology 2011, 99, 112-117. [CrossRef] [PubMed]

24. Gortner, L.; Reiss, I.; Hilgendorff, A. Bronchopulmonary dysplasia and intrauterine growth restriction. Lancet 2006, 368, 28. [CrossRef] 
25. Bose, C.; Van Marter, L.J.; Laughon, M.; O’Shea, T.M.; Allred, E.N.; Karna, P.; Ehrenkranz, R.A.; Boggess, K.; Leviton, A. Fetal growth restriction and chronic lung disease among infants born before the 28th week of gestation. Pediatrics 2009, 124, e450. [CrossRef]

26. Abman, S.H. Bronchopulmonary dysplasia: "A vascular hypothesis. " Am. J. Respir. Crit. Care Med. 2001, 164, 1755-1756. [CrossRef]

27. Sehgal, A.; Gwini, S.M.; Menahem, S.; Allison, B.J.; Miller, S.L.; Polglase, G.R. Preterm growth restriction and bronchopulmonary dysplasia: The vascular hypothesis and related physiology. J. Physiol. 2019, 597, 1209-1220. [CrossRef]

28. Eriksson, L.; Haglund, B.; Odlind, V.; Altman, M.; Kieler, H. Prenatal inflammatory risk factors for development of bronchopulmonary dysplasia. Pediatr. Pulmonol. 2014, 49, 665-672. [CrossRef]

29. Yu, K.F.; Ph, D.; Maynard, S.E.; Sachs, B.P.; Sibai, B.M.; Epstein, F.H.; Romero, R.; Thadhani, R.; Karumanchi, S.A. Soluble Endoglin and Other Circulating Antiangiogenic Factors in Preeclampsia. N. Engl. J. Med. 2006, 355, 992-1005. [CrossRef]

30. Ozkan, H.; Cetinkaya, M.; Koksal, N. Increased incidence of bronchopulmonary dysplasia in preterm infants exposed to preeclampsia. J. Matern. Neonatal Med. 2012, 25, 2681-2685. [CrossRef]

31. Torchin, H.; Ancel, P.Y.; Goffinet, F.; Hascoët, J.M.; Truffert, P.; Tran, D.; Lebeaux, C.; Jarreau, P.H. Placental complications and bronchopulmonary dysplasia: EPIPAGE-2 cohort study. Pediatrics 2016, 137, e20152163. [CrossRef]

32. Yoon, B.H.; Romero, R.; Jun, J.K.; Park, K.H.; Park, J.D.; Ghezzi, F.; Kim, B. Il Amniotic fluid cytokines (interleukin-6, tumor necrosis factor- $\alpha$, interleukin-1 $\beta$, and interleukin-8) and the risk for the development of bronchopulmonary dysplasia. Am. J. Obstet. Gynecol. 1997, 177, 825-830. [CrossRef]

33. Baraldi, E.; Giordano, G.; Stocchero, M.; Moschino, L.; Zaramella, P.; Tran, M.R.; Carraro, S.; Romero, R.; Gervasi, M.T. Untargeted metabolomic analysis of amniotic fluid in the prediction of preterm delivery and bronchopulmonary dysplasia. PLoS ONE 2016, 11, e0164211. [CrossRef]

34. Fanos, V.; Cristina Pintus, M.; Lussu, M.; Atzori, L.; Noto, A.; Stronati, M.; Guimaraes, H.; Marcialis, M.A.; Rocha, G.; Moretti, C.; et al. Urinary metabolomics of bronchopulmonary dysplasia (BPD): Preliminary data at birth suggest it is a congenital disease. J. Matern. Neonatal Med. 2014, 27, 39-45. [CrossRef]

35. Ballard, A.R.; Mallett, L.H.; Pruszynski, J.E.; Cantey, J.B. Chorioamnionitis and subsequent bronchopulmonary dysplasia in very-low-birth weight infants: A 25-year cohort. J. Perinatol. 2016, 36, 1045-1048. [CrossRef] [PubMed]

36. Morrow, L.A.; Wagner, B.D.; Ingram, D.A.; Poindexter, B.B.; Schibler, K.; Cotten, C.M.; Dagle, J.; Sontag, M.K.; Mourani, P.M.; Abman, S.H. Antenatal determinants of bronchopulmonary dysplasia and late respiratory disease in preterm infants. Am. J. Respir. Crit. Care Med. 2017, 196, 364-374. [CrossRef] [PubMed]

37. Sekhon, H.S.; Keller, J.A.; Benowitz, N.L.; Spindel, E.R. Prenatal nicotine exposure alters pulmonary function in newborn rhesus monkeys. Am. J. Respir. Crit. Care Med. 2001, 164, 989-994. [CrossRef]

38. Macaubas, C.; De Klerk, N.H.; Holt, B.J.; Wee, C.; Kendall, G.; Firth, M.; Sly, P.D.; Holt, P.G. Association between antenatal cytokine production and the development of atopy and asthma at age 6 years. Lancet 2003, 362, 1192-1197. [CrossRef]

39. Jensen, E.A.; Schmidt, B. Epidemiology of bronchopulmonary dysplasia. Birth Defects Res. Part. A Clin. Mol. Teratol. 2014, 100, 145-157. [CrossRef]

40. Klinger, G.; Sokolover, N.; Boyko, V.; Sirota, L.; Lerner-Geva, L.; Reichman, B. Perinatal risk factors for bronchopulmonary dysplasia in a national cohort of very-low-birthweight infants. Am. J. Obstet. Gynecol. 2013, 208, 115.e1-115.e9. [CrossRef]

41. Bhandari, V. Familial and genetic susceptibility to major neonatal morbidities in preterm twins. Pediatrics 2006, 117, 1901-1906. [CrossRef]

42. Lavoie, P.M.; Pham, C.; Jang, K.L. Heritability of bronchopulmonary dysplasia, defined according to the consensus statement of the national institutes of health. Pediatrics 2008, 122, 479-485. [CrossRef] [PubMed]

43. Warburton, D. Developmental responses to lung injury: Repair or fibrosis. Fibrogenesis Tissue Repair 2012, 5, S2. [CrossRef] [PubMed]

44. Warburton, D.; Tefft, D.; Mailleux, A.; Bellusci, S.; Thiery, J.P.; Zhao, J.; Buckley, S.; Shi, W.; Driscoll, B. Do lung remodeling, repair, and regeneration recapitulate respiratory ontogeny? Am. J. Respir. Crit. Care Med. 2001, 164, S59-S62. [CrossRef] [PubMed] 
45. Ambalavanan, N.; Michael Cotten, C.; Page, G.P.; Carlo, W.A.; Murray, J.C.; Bhattacharya, S.; Mariani, T.J.; Cuna, A.C.; Faye-Petersen, O.M.; Kelly, D.; et al. Integrated genomic analyses in bronchopulmonary dysplasia. J. Pediatr. 2015, 166, 531-537. [CrossRef] [PubMed]

46. Lal, C.V.; Ambalavanan, N. Genetic predisposition to bronchopulmonary dysplasia. Semin. Perinatol. 2015, 39, 584-591. [CrossRef]

47. Hamvas, A.; Feng, R.; Bi, Y.; Wang, F.; Bhattacharya, S.; Mereness, J.; Kaushal, M.; Cotten, C.M.; Ballard, P.L.; Mariani, T.J.; et al. Exome sequencing identifies gene variants and networks associated with extreme respiratory outcomes following preterm birth. BMC Genet. 2018, 19, 1-10. [CrossRef]

48. Gentle, S.J.; Lal, C.V. Predicting BPD: Lessons Learned From the Airway Microbiome of Preterm Infants. Front. Pediatr. 2020, 7, 564. [CrossRef]

49. Zhu, J.J.; Bao, Y.Y.; Zhang, G.L.; Ma, L.X.; Wu, M.Y. No relationship between mode of delivery and neonatal mortality and neurodevelopment in very low birth weight infants aged two years. World J. Pediatr. 2014, 10, 227-231. [CrossRef]

50. Laughon, M.M.; Langer, J.C.; Bose, C.L.; Smith, P.B.; Ambalavanan, N.; Kennedy, K.A.; Stoll, B.J.; Buchter, S.; Laptook, A.R.; Ehrenkranz, R.A.; et al. Prediction of Bronchopulmonary Dysplasia by Postnatal Age in Extremely Premature Infants. Am. J. Respir. Crit. Care Med. 2011, 183, 1715-1722. [CrossRef]

51. Ito, M.; Tamura, M.; Namba, F. Role of sex in morbidity and mortality of very premature neonates. Pediatr. Int. 2017, 59, 898-905. [CrossRef]

52. Lingappan, K.; Jiang, W.; Wang, L.; Moorthy, B. Sex-specific differences in neonatal hyperoxic lung injury. Am. J. Physiol. Lung Cell. Mol. Physiol. 2016, 311, L481-L493. [CrossRef]

53. Ryan, R.M.; Feng, R.; Bazacliu, C.; Ferkol, T.W.; Ren, C.L.; Mariani, T.J.; Poindexter, B.B.; Wang, F.; Moore, P.E.; Chougnet, C.; et al. Black race is associated with a lower risk of bronchopulmonary dysplasia. J. Pediatr. 2019, 207, 130-135. [CrossRef] [PubMed]

54. Frank, L.; Ilene Sosenko, R.S. Development of lung antioxidant enzyme system in late gestation: Possible implications for the prematurely born infant. J. Pediatr. 1987, 110, 9-14. [CrossRef]

55. Wai, K.C.; Kohn, M.A.; Ballard, R.A.; Truog, W.E.; Black, D.M.; Asselin, J.M.; Ballard, P.L.; Rogers, E.E.; Keller, R.L. Early cumulative supplemental oxygen predicts bronchopulmonary dysplasia in high risk extremely low gestational age newborns. J. Pediatr. 2016, 177, 97-102. [CrossRef] [PubMed]

56. Ratner, V.; Starkov, A.; Matsiukevich, D.; Polin, R.A.; Ten, V.S. Mitochondrial dysfunction contributes to alveolar developmental arrest in hyperoxia-exposed mice. Am. J. Respir. Cell Mol. Biol. 2009, 40, 511-518. [CrossRef] [PubMed]

57. Balasubramaniam, V.; Mervis, C.F.; Maxey, A.M.; Markham, N.E.; Abman, S.H. Hyperoxia reduces bone marrow, circulating, and lung endothelial progenitor cells in the developing lung: Implications for the pathogenesis of bronchopulmonary dysplasia. AJP Lung Cell. Mol. Physiol. 2007, 292, L1073-L1084. [CrossRef] [PubMed]

58. Baker, C.D.; Balasubramaniam, V.; Mourani, P.M.; Sontag, M.K.; Black, C.P.; Ryan, S.L.; Abman, S.H. Cord blood angiogenic progenitor cells are decreased in bronchopulmonary dysplasia. Eur. Respir. J. 2012, 40, 1516-1522. [CrossRef]

59. Dreyfuss, D.; Saumon, G. Role of tidal volume, FRC, and end-inspiratory volume in the development of pulmonary edema following mechanical ventilation. Am. Rev. Respir. Dis. 1993, 148, 1194-1203. [CrossRef]

60. Mourgeon, E.; Isowa, N.; Keshavjee, S.; Zhang, X.; Slutsky, A.S.; Liu, M. Mechanical stretch stimulates macrophage inflammatory protein-2 secretion from fetal rat lung cells. Am. J. Physiol. Lung Cell. Mol. Physiol. 2000, 279, L699-L706. [CrossRef]

61. Ricard, J.D.; Dreyfuss, D.; Saumon, G. Production of inflammatory cytokines in ventilator-induced lung injury: A reappraisal. Am. J. Respir. Crit. Care Med. 2001, 163, 1176-1180. [CrossRef]

62. Ratner, V.; Sosunov, S.A.; Niatsetskaya, Z.V.; Utkina-Sosunova, I.V.; Ten, V.S. Mechanical ventilation causes pulmonary mitochondrial dysfunction and delayed alveolarization in neonatal mice. Am. J. Respir. Cell Mol. Biol. 2013, 49, 943-950. [CrossRef] [PubMed]

63. Hascoët, J.M.; Picaud, J.C.; Ligi, I.; Blanc, T.; Moreau, F.; Pinturier, M.F.; Zupan, V.; Guilhoto, I.; Hamon, I.R.M.; Alexandre, C.; et al. Late surfactant administration in very preterm neonates with prolonged respiratory distress and pulmonary outcome at 1 year of age: A randomized clinical trial. JAMA Pediatr. 2016, 170, 365-372. [CrossRef] [PubMed] 
64. Ballard, P.L.; Keller, R.L.; Truog, W.E.; Chapin, C.; Horneman, H.; Segal, M.R.; Ballard, R.A. Tolsurf Investigators Surfactant status and respiratory outcome in premature infants receiving late surfactant treatment. Pediatr. Res. 2018, 305-311. [CrossRef]

65. Lahra, M.M.; Beeby, P.J.; Jeffery, H.E. Intrauterine inflammation, neonatal sepsis, and chronic lung disease: A 13-year hospital cohort study. Pediatrics 2009, 123, 1314-1319. [CrossRef] [PubMed]

66. Dong, Y.; Glaser, K.; Schlegel, N.; Claus, H.; Speer, C.P. An underestimated pathogen: Staphylococcus epidermidis induces pro-inflammatory responses in human alveolar epithelial cells. Cytokine 2019, 123, 154761. [CrossRef]

67. Rojas, M.A.; Gonzalez, A.; Bancalari, E.; Claure, N.; Poole, C.; Silva-Neto, G. Changing trends in the epidemiology and pathogenesis of neonatal chronic lung disease. J. Pediatr. 1995, 126, 605-610. [CrossRef]

68. Marsland, B.J.; Gollwitzer, E.S. Host-microorganism interactions in lung diseases. Nat. Rev. Immunol. 2014, 14, 827-835. [CrossRef]

69. Surana, N.K.; Kasper, D.L. Deciphering the tête-è-tête between the microbiota and the immune system. J. Clin. Investig. 2014, 124, 4197-4203. [CrossRef]

70. Lohmann, P.; Luna, R.A.; Hollister, E.B.; Devaraj, S.; Mistretta, T.A.; Welty, S.E.; Versalovic, J. The airway microbiome of intubated premature infants: Characteristics and changes that predict the development of bronchopulmonary dysplasia. Pediatr. Res. 2014, 76, 294-301. [CrossRef]

71. Lal, C.V.; Travers, C.; Aghai, Z.H.; Eipers, P.; Jilling, T.; Halloran, B.; Carlo, W.A.; Keeley, J.; Rezonzew, G.; Kumar, R.; et al. The airway microbiome at birth. Sci. Rep. 2016, 6, 31023. [CrossRef]

72. Segal, L.N.; Clemente, J.C.; Wu, B.G.; Wikoff, W.R.; Gao, Z.; Li, Y.; Ko, J.P.; Rom, W.N.; Blaser, M.J.; Weiden, M.D. Randomised, double-blind, placebo-controlled trial with azithromycin selects for anti-inflammatory microbial metabolites in the emphysematous lung. Thorax 2017, 72, 13-22. [CrossRef]

73. Marsland, B.J. Regulating inflammation with microbial metabolites. Nat. Med. 2016, 22, 581-583. [CrossRef] [PubMed]

74. Wedgwood, S.; Warford, C.; Agvateesiri, S.C.; Thai, P.; Berkelhamer, S.K.; Perez, M.; Underwood, M.A.; Steinhorn, R.H. Postnatal growth restriction augments oxygen-induced pulmonary hypertension in a neonatal rat model of bronchopulmonary dysplasia. Pediatr. Res. 2016, 80, 894-902. [CrossRef] [PubMed]

75. Klevebro, S.; Lundgren, P.; Hammar, U.; Smith, L.E.; Bottai, M.; Domellöf, M.; Löfqvist, C.; Hallberg, B.; Hellström, A. Cohort study of growth patterns by gestational age in preterm infants developing morbidity. BMJ Open 2016, 6, 12872. [CrossRef] [PubMed]

76. Underwood, M.A.; Wedgwood, S.; Lakshminrusimha, S.; Steinhorn, R.H. Somatic growth and the risks of bronchopulmonary dysplasia and pulmonary hypertension: Connecting epidemiology and physiology1. Can. J. Physiol. Pharmacol. 2019, 97, 197-205. [CrossRef] [PubMed]

77. Stephens, B.E.; Walden, R.V.; Gargus, R.A.; Tucker, R.; McKinley, L.; Mance, M.; Nye, J.; Vohr, B.R. First-week protein and energy intakes are associated with 18-month developmental outcomes in extremely low birth weight infants. Pediatrics 2009, 123, 1337-1343. [CrossRef]

78. Prince, L.R.; Maxwell, N.C.; Gill, S.K.; Dockrell, D.H.; Sabroe, I.; McGreal, E.P.; Kotecha, S.; Whyte, M.K. Macrophage phenotype is associated with disease severity in preterm infants with chronic lung disease. PLoS ONE 2014, 9, e103059. [CrossRef]

79. Kalymbetova, T.V.; Selvakumar, B.; Rodríguez-Castillo, J.A.; Gunjak, M.; Malainou, C.; Heindl, M.R.; Moiseenko, A.; Chao, C.M.; Vadász, I.; Mayer, K.; et al. Resident alveolar macrophages are master regulators of arrested alveolarization in experimental bronchopulmonary dysplasia. J. Pathol. 2018, 245, $153-159$. [CrossRef]

80. Milan, A.; Priante, E.; Zaramella, P.; Nardo, D.; Tosato, F.; Pantano, G.; Baraldi, E. Early macrophage activation in preterm newborns and respiratory disease. J. Child. Sci. 2017, 7, e110-e119. [CrossRef]

81. Matthay, M.A.; Ware, L.B.; Zimmerman, G.A. The acute respiratory distress syndrome. J. Clin. Investig. 2012, 122, 2731-2740. [CrossRef]

82. Jones, H.R.; Robb, C.T.; Perretti, M.; Rossi, A.G. The role of neutrophils in inflammation resolution. Semin. Immunol. 2016, 28, 137-145. [CrossRef] [PubMed]

83. Johnson, D.E.; Kulik, T.J.; Lock, J.E.; Elde, R.P.; Thompson, T.R. Bombesin-, calcitonin-, and serotonin-immunoreactive pulmonary neuroendocrine cells in acute and chronic neonatal lung disease. Pediatr. Pulmonol. 1985, 1, 13-20. 
84. Cullen, A.; Van Marter, L.J.; Allred, E.N.; Moore, M.; Parad, R.B.; Sunday, M.E. Urine bombesin-like peptide elevation precedes clinical evidence of bronchopulmonary dysplasia. Am. J. Respir. Crit. Care Med. 2002, 165, 1093-1097. [CrossRef] [PubMed]

85. Shenberger, J.S.; Shew, R.L.; Johnson, D.E. Hyperoxia-induced airway remodeling and pulmonary neuroendocrine cell hyperplasia in the weanling rat. Pediatr. Res. 1997, 42, 539-544. [CrossRef]

86. Möbius, M.A.; Thébaud, B. Bronchopulmonary dysplasia: Where have all the stem cells gone? Origin and (potential) function of resident lung stem cells. Chest 2017, 152, 1043-1052. [CrossRef]

87. Balasubramaniam, V.; Ryan, S.L.; Seedorf, G.J.; Roth, E.V.; Heumann, T.R.; Yoder, M.C.; Ingram, D.A.; Hogan, C.J.; Markham, N.E.; Abman, S.H. Bone marrow-derived angiogenic cells restore lung alveolar and vascular structure after neonatal hyperoxia in infant mice. Am. J. Physiol. Lung Cell. Mol. Physiol. 2010, 298, 315-323. [CrossRef]

88. Fujinaga, H.; Baker, C.D.; Ryan, S.L.; Markham, N.E.; Seedorf, G.J.; Balasubramaniam, V.; Abman, S.H. Hyperoxia disrupts vascular endothelial growth factor-nitric oxide signaling and decreases growth of endothelial colony-forming cells from preterm infants. Am. J. Physiol. Lung Cell. Mol. Physiol. 2009, 297, L1160-L1169. [CrossRef]

89. Balany, J.; Bhandari, V. Understanding the impact of infection, inflammation, and their persistence in the pathogenesis of bronchopulmonary dysplasia. Front. Med. 2015, 2, 90. [CrossRef]

90. Groneck, P.; Götze-Speer, B.; Oppermann, M.; Eiffert, H.; Speer, C.P. Association of pulmonary inflammation and increased microvascular permeability during the development of bronchopulmonary dysplasia: A sequential analysis of inflammatory mediators in respiratory fluids of high-risk preterm neonates. Pediatrics 1994, 93, 712-718.

91. Alejandre-Alcazar, M.A.; Kwapiszewska, G.; Reiss, I.; Amarie, O.V.; Marsh, L.M.; Sevilla-Perez, J.; Wygrecka, M.; Eul, B.; Kobrich, S.; Hesse, M.; et al. Hyperoxia modulates TGF-beta/BMP signaling in a mouse model of bronchopulmonary dysplasia. AJP Lung Cell. Mol. Physiol. 2006, 292, L537-L549. [CrossRef]

92. Nakanishi, H.; Sugiura, T.; Streisand, J.B.; Lonning, S.M.; Roberts, J.D. TGF-beta-neutralizing antibodies improve pulmonary alveologenesis and vasculogenesis in the injured newborn lung. AJP Lung Cell. Mol. Physiol. 2007, 293, L151-L161. [CrossRef] [PubMed]

93. Leroy, S.; Caumette, E.; Waddington, C.; Hébert, A.; Brant, R.; Lavoie, P.M. A time-based analysis of Inflammation in infants at risk of bronchopulmonary dysplasia. J. Pediatr. 2018, 192, 60-65. [CrossRef] [PubMed]

94. Löfqvist, C.; Hellgren, G.; Niklasson, A.; Engström, E.; Ley, D.; Hansen-Pupp, I. Low postnatal serum IGF-I levels are associated with bronchopulmonary dysplasia (BPD). Acta Paediatr. Int. J. Paediatr. 2012, 101, 1211-1216. [CrossRef] [PubMed]

95. Capoluongo, E.; Ameglio, F.; Zuppi, C. Insulin-like growth factor-I and complications of prematurity: A focus on bronchopulmonary dysplasia. Clin. Chem. Lab. Med. 2008, 46, 1061-1066. [CrossRef] [PubMed]

96. Hellström, A.; Ley, D.; Hansen-Pupp, I.; Hallberg, B.; Ramenghi, L.A.; Löfqvist, C.; Smith, L.E.H.; Hård, A.L. Role of insulinlike growth factor 1 in fetal development and in the early postnatal life of premature infants. Am. J. Perinatol. 2016, 33, 1067-1071. [CrossRef] [PubMed]

97. Yılmaz, C.; Köksal, N.; Özkan, H.; Dorum, B.A.; Bağc1, O. Low serum igf-1 and increased cytokine levels in tracheal aspirate samples are associated with bronchopulmonary dysplasia. Turk. J. Pediatr. 2017, 59, 122. [CrossRef]

98. Capoluongo, E.; Concolino, P.; Giardina, B.; Zuppi, C.; Ameglio, F.; Vento, G.; Romagnoli, C. Is there a relationship between ELF free-IGF-1 levels and fibrotic process enhancement characterizing CLD development in neutropenic premature babies? Pediatr. Pulmonol. 2006, 41, 286-287. [CrossRef]

99. Chetty, A.; Andersson, S.; Lassus, P.; Nielsen, H.C. Insulin-Like Growth Factor-1 (IGF-1) and IGF-1 Receptor (IGF-1R) expression in human lung in RDS and BPD. Pediatr. Pulmonol. 2004, 37, 128-136. [CrossRef]

100. Stahl, A.; Connor, K.M.; Sapieha, P.; Chen, J.; Dennison, R.J.; Krah, N.M.; Seaward, M.R.; Willett, K.L.; Aderman, C.M.; Guerin, K.I.; et al. The mouse retina as an angiogenesis model. Investig. Opthalmology Vis. Sci. 2010, 51, 2813. [CrossRef]

101. Thébaud, B.; Abman, S.H. Bronchopulmonary dysplasia: Where have all the vessels gone? Roles of angiogenic growth factors in chronic lung disease. Am. J. Respir. Crit. Care Med. 2007, 175, 978-985. [CrossRef] 
102. Sunday, M.E.; Yoder, B.A.; Cuttitta, F.; Haley, K.J.; Emanuel, R.L. Bombesin-like peptide mediates lung injury in a baboon model of bronchopulmonary dysplasia. J. Clin. Investig. 1998, 102, 584-594. [CrossRef] [PubMed]

103. Janér, J.; Andersson, S.; Kajantie, E.; Lassus, P. Endostatin concentration in cord plasma predicts the development of bronchopulmonary dysplasia in very low birth weight infants. Pediatrics 2009, 123, 1142-1146. [CrossRef] [PubMed]

104. Mourani, P.M.; Abman, S.H. Pulmonary hypertension and vascular abnormalities in bronchopulmonary dysplasia. Clin. Perinatol. 2015, 42, 839-855. [CrossRef]

105. Baker, C.D.; Abman, S.H. Impaired pulmonary vascular development in bronchopulmonary dysplasia. Neonatology 2015, 107, 344-351. [CrossRef] [PubMed]

106. Le Cras, T.D.; Markham, N.E.; Tuder, R.M.; Voelkel, N.F.; Abman, S.H. Treatment of newborn rats with a VEGF receptor inhibitor causes pulmonary hypertension and abnormal lung structure. Am. J. Physiol. Lung Cell. Mol. Physiol. 2002, 283, L555-L562. [CrossRef] [PubMed]

107. Hendricks-Muñoz, K.D.; Xu, J.; Voynow, J.A. Tracheal aspirate VEGF and sphingolipid metabolites in the preterm infant with later development of bronchopulmonary dysplasia. Pediatr. Pulmonol. 2018, 53, 1046-1052. [CrossRef]

108. Bhatt, A.J.; Pryhuber, G.S.; Huyck, H.; Watkins, R.H.; Metlay, L.A.; Maniscalco, W.M. Disrupted pulmonary vasculature and decreased vascular endothelial growth factor, Flt-1, and TIE-2 in human infants dying with bronchopulmonary dysplasia. Am. J. Respir. Crit. Care Med. 2001, 164, 1971-1980. [CrossRef]

109. Berger, J.; Bhandari, V. Animal models of bronchopulmonary dysplasia. The term mouse models. AJP Lung Cell. Mol. Physiol. 2014, 307, L936-L947. [CrossRef]

110. O'Reilly, M.; Thebaud, B. Animal models of bronchopulmonary dysplasia. The term rat models. AJP Lung Cell. Mol. Physiol. 2014, 307, L948-L958. [CrossRef]

111. D'Angio, C.T.; Ryan, R.M.; Angio, C.T.D.; Ryan, R.M. Animal models of bronchopulmonary dysplasia. The preterm and term rabbit models. Am. J. Physiol. Lung Cell. Mol. Physiol. 2014, 307, L959-L969. [CrossRef]

112. Albertine, K.H. Utility of large-animal models of BPD: Chronically ventilated preterm lambs. Am. J. Physiol. Lung Cell. Mol. Physiol. 2015, 308, L983-L1001. [CrossRef]

113. Yoder, B.A.; Coalson, J.J. Animal models of bronchopulmonary dysplasia. The preterm baboon models. Am. J. Physiol. Cell. Mol. Physiol. 2014, 307, L970-L977. [CrossRef] [PubMed]

114. Nardiello, C.; Mižíková, I.; Silva, D.M.; Ruiz-Camp, J.; Mayer, K.; Vadász, I.; Herold, S.; Seeger, W.; Morty, R.E. Standardisation of oxygen exposure in the development of mouse models for bronchopulmonary dysplasia. Dis. Model. Mech. 2017, 10, 185-196. [CrossRef] [PubMed]

115. Hsia, C.C.W.; Hyde, D.M.; Ochs, M.; Weibel, E.R. An Official Research Policy Statement of the American Thoracic Society/European Respiratory Society: Standards for Quantitative Assessment of Lung Structure. Am. J. Respir. Crit. Care Med. 2010, 181, 394-418. [CrossRef] [PubMed]

116. Mühlfeld, C.; Ochs, M. Quantitative microscopy of the lung: A problem-based approach. Part 2: Stereological parameters and study designs in various diseases of the respiratory tract. Am. J. Physiol. Cell. Mol. Physiol. 2013, 305, L205-L221. [CrossRef]

117. Ochs, M.; Mühlfeld, C. Quantitative microscopy of the lung: A problem-based approach. Part 1: Basic principles of lung stereology. Am. J. Physiol. Cell. Mol. Physiol. 2013, 305, L15-L22. [CrossRef]

118. Porzionato, A.; Guidolin, D.; Macchi, V.; Sarasin, G.; Grisafi, D.; Tortorella, C.; Dedja, A.; Zaramella, P.; De Caro, R. Fractal analysis of alveolarization in hyperoxia-induced rat models of bronchopulmonary dysplasia. Am. J. Physiol. Cell. Mol. Physiol. 2016, 310, L680-L688. [CrossRef]

119. Sallon, C.; Soulet, D.; Tremblay, Y. Morphometry of pulmonary tissue: From manual to high throughput automation. Rev. Mal. Respir. 2017, 34, 1072-1084. [CrossRef]

120. Roberts, D.; Brown, J.; Medley, N.; Dalziel, S.R. Antenatal corticosteroids for accelerating fetal lung maturation for women at risk of preterm birth. Cochrane Database Syst. Rev. 2017, 3, CD004454. [CrossRef]

121. Seger, N.; Soll, R. Animal derived surfactant extract for treatment of respiratory distress syndrome. In Cochrane Database of Systematic Reviews; Seger, N., Ed.; John Wiley \& Sons, Ltd.: Chichester, UK, 2009; p. CD007836. [CrossRef]

122. Herting, E. Less invasive surfactant administration (LISA) - Ways to deliver surfactant in spontaneously breathing infants. Early Hum. Dev. 2013, 89, 875-880. [CrossRef] 
123. Aldana-Aguirre, J.C.; Pinto, M.; Featherstone, R.M.; Kumar, M. Less invasive surfactant administration versus intubation for surfactant delivery in preterm infants with respiratory distress syndrome: A systematic review and meta-analysis. Arch. Dis. Child. Fetal Neonatal Ed. 2017, 102, F17-F23. [CrossRef]

124. Gortner, L.; Schüller, S.S.; Herting, E. Review demonstrates that less invasive surfactant administration in preterm neonates leads to fewer complications. Acta Paediatr. 2017, 107, 736-743. [CrossRef] [PubMed]

125. Stenson, B.J.; Tarnow-Mordi, W.O.; Darlow, B.A.; Simes, J.; Juszczak, E.; Askie, L.; Battin, M.; BOOST II United Kingdom Collaborative Group; BOOST II Australia Collaborative Group; BOOST II New Zealand Collaborative Group (Eds.) Oxygen saturation and outcomes in preterm infants. N. Engl. J. Med. 2013, 368, 2094-2104. [CrossRef] [PubMed]

126. Schmidt, B.; Roberts, R.S.; Davis, P.; Doyle, L.W.; Barrington, K.J.; Ohlsson, A.; Solimano, A.; Tin, W. Long-term effects of caffeine therapy for apnea of prematurity. N. Engl. J. Med. 2007, 357, 1893-1902. [CrossRef] [PubMed]

127. Doyle, L.W.; Ranganathan, S.; Cheong, J.L.Y. Neonatal caffeine treatment and respiratory function at 11 years in children under 1, $251 \mathrm{~g}$ at Birth. Am. J. Respir. Crit. Care Med. 2017, 196, 1318-1324. [CrossRef]

128. Jobe, A.H. Caffeine: A Lung Drug for All Very Low Birth Weight Preterm Infants? Am. J. Respir. Crit. Care Med. 2017, 196, 1241-1243. [CrossRef]

129. Dumpa, V.; Nielsen, L.; Wang, H.; Kumar, V.H.S. Caffeine is associated with improved alveolarization and angiogenesis in male mice following hyperoxia induced lung injury. BMC Pulm. Med. 2019, 19, 138. [CrossRef]

130. Schwartz, E.; Zelig, R.; Parker, A.; Johnson, S. Vitamin A supplementation for the prevention of bronchopulmonary dysplasia in preterm infants: An update. Nutr. Clin. Pract. 2017, 32, 346-353. [CrossRef]

131. Deep Garg, B.; Bansal, A.; Kabra, N.S. Role of vitamin A supplementation in prevention of Bronchopulmonary dysplasia in extremely low birth weight neonates: A systematic review of randomized trials. J. Matern. Neonatal Med. 2019, 32, 2608-2615. [CrossRef]

132. Darlow, B.A.; Graham, P.J.; Rojas-Reyes, M.X. Vitamin A supplementation to prevent mortality and shortand long-term morbidity in very low birth weight infants. Cochrane Database Syst. Rev. 2016, CD000501. [CrossRef]

133. Ambalavanan, N.; Tyson, J.E.; Kennedy, K.A.; Hansen, N.I.; Vohr, B.R.; Wright, L.L.; Carlo, W.A. National institute of child health and human development neonatal research network vitamin a supplementation for extremely low birth weight infants: Outcome at 18 to 22 months. Pediatrics 2005, 115, e249-e254. [CrossRef] [PubMed]

134. Basu, S.; Khanna, P.; Srivastava, R.; Kumar, A. Oral vitamin A supplementation in very low birth weight neonates: A randomized controlled trial. Eur. J. Pediatr. 2019, 178, 1255-1265. [CrossRef] [PubMed]

135. Araki, S.; Kato, S.; Namba, F.; Ota, E. Vitamin A to prevent bronchopulmonary dysplasia in extremely low birth weight infants: A systematic review and meta-analysis. PLOS ONE 2018, 13, e0207730. [CrossRef] [PubMed]

136. Liebowitz, M.; Clyman, R.I. Prophylactic indomethacin compared with delayed conservative management of the patent ductus arteriosus in extremely preterm infants: Effects on neonatal outcomes. J. Pediatr. 2017, 187, 119-126. [CrossRef]

137. Oh, W.; Poindexter, B.B.; Perritt, R.; Lemons, J.A.; Bauer, C.R.; Ehrenkranz, R.A.; Stoll, B.J.; Poole, K.; Wright, L.L. Association between fluid intake and weight loss during the first ten days of life and risk of bronchopulmonary dysplasia in extremely low birth weight infants. J. Pediatr. 2005, 147, 786-790. [CrossRef]

138. Nair, V.; Loganathan, P.; Soraisham, A.S. Azithromycin and other macrolides for prevention of bronchopulmonary dysplasia: A systematic review and meta-analysis. Neonatology 2014, 106, 337-347. [CrossRef]

139. Wemhöner, A.; Ortner, D.; Tschirch, E.; Strasak, A.; Rüdiger, M. Nutrition of preterm infants in relation to bronchopulmonary dysplasia. BMC Pulm. Med. 2011, 11, 7. [CrossRef]

140. Spiegler, J.; Preuß, M.; Gebauer, C.; Bendiks, M.; Herting, E.; Göpel, W.; Berghäuser, M.A.; Böckenholt, K.; Bohnhorst, B.; Böttger, R.; et al. Does Breastmilk influence the development of bronchopulmonary dysplasia? J. Pediatr. 2016, 169, 76-80. [CrossRef]

141. Villamor-Martínez, E.; Pierro, M.; Cavallaro, G.; Mosca, F.; Villamor, E. Mother's own milk and bronchopulmonary dysplasia: A systematic review and meta-analysis. Front. Pediatr. 2019, 7, 224. [CrossRef] 
142. Ehrenkranz, R.A. Growth in the neonatal intensive care unit influences neurodevelopmental and growth outcomes of extremely low birth weight infants. Pediatrics 2006, 117, 1253-1261. [CrossRef]

143. Ma, L.; Zhou, P.; Neu, J.; Lin, H.C. Potential Nutrients for Preventing or Treating Bronchopulmonary Dysplasia. Paediatr. Respir. Rev. 2017, 22, 83-88. [CrossRef] [PubMed]

144. Grisafi, D.; Tassone, E.; Dedja, A.; Oselladore, B.; Masola, V.; Guzzardo, V.; Porzionato, A.; Salmaso, R.; Albertin, G.; Artusi, C.; et al. L-citrulline prevents alveolar and vascular derangement in a rat model of moderate hyperoxia-induced lung injury. Lung 2012, 190, 419-430. [CrossRef] [PubMed]

145. Doyle, L.W.; Ehrenkranz, R.A.; Halliday, H.L. Dexamethasone treatment after the first week of life for bronchopulmonary dysplasia in preterm infants: A systematic review. Neonatology 2010, 98, 289-296. [CrossRef] [PubMed]

146. Burrows, B.; Cline, M.G.; Knudson, R.J.; Taussig, L.M.; Lebowitz, M.D. A descriptive analysis of the growth and decline of the FVC and FEV1. Chest 1983, 83, 717-724. [CrossRef]

147. Martinez, F.D. Early-life origins of chronic obstructive pulmonary disease. N. Engl. J. Med. 2016, 375, 871-878. [CrossRef]

148. Simpson, S.J.; Turkovic, L.; Wilson, A.C.; Verheggen, M.; Logie, K.M.; Pillow, J.J.; Hall, G.L. Lung function trajectories throughout childhood in survivors of very preterm birth: A longitudinal cohort study. Lancet Child. Adolesc. Health 2018, 2, 350-359. [CrossRef]

149. Kotecha, S.S.J.; Edwards, M.O.; Watkins, W.J.; Henderson, A.J.; Paranjothy, S.; Dunstan, F.D.; Kotecha, S.S.J. Effect of preterm birth on later FEV1: A systematic review and meta-analysis. Thorax 2013, 68, 760-766. [CrossRef]

150. Doyle, L.W.; Faber, B.; Callanan, C.; Freezer, N.; Ford, G.W.; Davis, N.M. Bronchopulmonary dysplasia in very low birth weight subjects and lung function in late adolescence. Pediatrics 2006, 118, 108-113. [CrossRef]

151. Vollsæter, M.; Clemm, H.H.; Satrell, E.; Eide, G.E.; Røksund, O.D.; Markestad, T.; Halvorsen, T. Adult respiratory outcomes of extreme preterm birth a regional cohort study. Ann. Am. Thorac. Soc. 2015, 12, 313-322. [CrossRef]

152. Hirata, K.; Nishihara, M.; Shiraishi, J.; Hirano, S.; Matsunami, K.; Sumi, K.; Wada, N.; Kawamoto, Y.; Nishikawa, M.; Nakayama, M.; et al. Perinatal factors associated with long-term respiratory sequelae in extremely low birthweight infants. Arch. Dis. Child. Fetal Neonatal Ed. 2015, 100, F314-F319. [CrossRef]

153. Hirata, K.; Nishihara, M.; Kimura, T.; Shiraishi, J.; Hirano, S.; Kitajima, H.; Fujimura, M. Longitudinal impairment of lung function in school-age children with extremely low birth weights. Pediatr. Pulmonol. 2017, 52, 779-786. [CrossRef]

154. Fortuna, M.; Carraro, S.; Temporin, E.; Berardi, M.; Zanconato, S.; Salvadori, S.; Lago, P.; Frigo, A.C.; Filippone, M.; Baraldi, E. Mid-childhood lung function in a cohort of children with "new bronchopulmonary dysplasia. " Pediatr. Pulmonol. 2016, 51, 1057-1064. [CrossRef] [PubMed]

155. Doyle, L.W.; Adams, A.M.; Robertson, C.; Ranganathan, S.; Davis, N.M.; Lee, K.J.; Cheong, J.L.; Anderson, P.; Burnett, A.; Callanan, C.; et al. Increasing airway obstruction from 8 to 18 years in extremely preterm/low-birthweight survivors born in the surfactant era. Thorax 2017, 72, 712-719. [CrossRef] [PubMed]

156. Moschino, L.; Carraro, S.; Zanconato, S.; Filippone, M.; Baraldi, E. Evaluation of lung function in BPD survivors from infancy to adulthood: The Padova BPD study. Am J Respir Crit Care Med. 2018, 198(1), 134-137. [CrossRef] [PubMed]

157. Moschino, L.; Carraro, S.; Baraldi, E. Early-life origin and prevention of chronic obstructive pulmonary diseases. Pediatr. Allergy Immunol. 2020, 31, 16-18. [CrossRef] [PubMed]

158. Filippone, M.; Bonetto, G.; Corradi, M.; Frigo, A.C.; Baraldi, E. Evidence of unexpected oxidative stress in airways of adolescents born very pre-term. Eur. Respir. J. 2012, 40, 1253-1259. [CrossRef]

159. Galderisi, A.; Calabrese, F.; Fortarezza, F.; Abman, S.; Baraldi, E. Airway histopathology of adolescent survivors of Bronchopulmonary Dysplasia. J. Pediatr. 2019, 211, 215-218. [CrossRef]

160. Lal, C.V.; Ambalavanan, N. Cellular and humoral biomarkers of Bronchopulmonary Dysplasia. Early Hum. Dev. 2017, 105, 35-39. [CrossRef]

161. Noto, A.; Fanos, V.; Dessì, A. Metabolomics in newborns. In Advances in Clinical Chemistry; Elsevier: Amsterdam, The Netherlands, 2016; Volume 74, pp. 35-61. [CrossRef]

162. Piersigilli, F.; Bhandari, V. Biomarkers in neonatology: The new "omics" of bronchopulmonary dysplasia. J. Matern. Neonatal Med. 2016, 29, 1758-1764. [CrossRef] 
163. Rivera, L.; Siddaiah, R.; Oji-Mmuo, C.; Silveyra, G.R.; Silveyra, P. Biomarkers for bronchopulmonary dysplasia in the preterm infant. Front. Pediatr. 2016, 4, 33. [CrossRef]

164. Förster, K.; Sass, S.; Ehrhardt, H.; Mous, D.S.; Rottier, R.J.; Oak, P.; Schulze, A.; Flemmer, A.W.; Gronbach, J.; Hübener, C.; et al. Early identification of bronchopulmonary dysplasia using novel biomarkers by proteomic screening. Am. J. Respir. Crit. Care Med. 2017, 197, 1076-1080. [CrossRef] [PubMed]

165. Cuna, A.; Liu, C.; Govindarajan, S.; Queen, M.; Dai, H.; Truog, W.E. Usefulness of an online risk estimator for bronchopulmonary dysplasia in predicting corticosteroid treatment in infants born preterm. J. Pediatr. 2018, 197, 23-28. [CrossRef]

166. Higano, N.S.; Spielberg, D.R.; Fleck, R.J.; Schapiro, A.H.; Walkup, L.L.; Hahn, A.D.; Tkach, J.A.; Kingma, P.S.; Merhar, S.L.; Fain, S.B.; et al. Neonatal pulmonary magnetic resonance imaging of bronchopulmonary dysplasia predicts short-term clinical outcomes. Am. J. Respir. Crit. Care Med. 2018, 198, 1302-1311. [CrossRef] [PubMed]

167. Alonso-Ojembarrena, A.; Lubián-López, S.P. Lung ultrasound score as early predictor of bronchopulmonary dysplasia in very low birth weight infants. Pediatr. Pulmonol. 2019, 54, 1404-1409. [CrossRef] [PubMed]

168. Filippone, M.; Nardo, D.; Bonadies, L.; Salvadori, S.; Baraldi, E. Update on postnatal corticosteroids to prevent or treat bronchopulmonary dysplasia. Am. J. Perinatol. 2019, 36, S58-S62. [CrossRef] [PubMed]

169. Doyle, L.W.; Halliday, H.L.; Ehrenkranz, R.A.; Davis, P.G.; Sinclair, J.C. An update on the impact of postnatal systemic corticosteroids on mortality and cerebral palsy in preterm infants: Effect modification by risk of bronchopulmonary dysplasia. J. Pediatr. 2014, 165, 1258-1260. [CrossRef]

170. Onland, W.; De Jaegere, A.P.; Offringa, M.; van Kaam, A. Systemic corticosteroid regimens for prevention of bronchopulmonary dysplasia in preterm infants. Cochrane Database Syst. Rev. 2017, 1, CD010941. [CrossRef]

171. Baud, O.; Trousson, C.; Biran, V.; Leroy, E.; Mohamed, D.; Alberti, C. PREMILOC trial group association between early low-dose hydrocortisone therapy in extremely preterm neonates and neurodevelopmental outcomes at 2 years of age. JAMA 2017, 317, 1329. [CrossRef]

172. Baud, O.; Maury, L.; Lebail, F.; Ramful, D.; El Moussawi, F.; Nicaise, C.; Zupan-Simunek, V.; Coursol, A.; Beuchée, A.; Bolot, P.; et al. Effect of early low-dose hydrocortisone on survival without bronchopulmonary dysplasia in extremely preterm infants (PREMILOC): A double-blind, placebo-controlled, multicentre, randomised trial. Lancet 2016, 387, 1827-1836. [CrossRef]

173. Yeh, T.F.; Chen, C.M.; Wu, S.Y.; Husan, Z.; Li, T.C.; Hsieh, W.S.; Tsai, C.H.; Lin, H.C. Intratracheal administration of budesonide/surfactant to prevent bronchopulmonary dysplasia. Am. J. Respir. Crit. Care Med. 2016, 193, 86-95. [CrossRef]

174. Bancalari, E.; Jain, D.; Jobe, A.H. Prevention of Bronchopulmonary Dysplasia: Are Intratracheal Steroids with Surfactant a Magic Bullet? Am. J. Respir. Crit. Care Med. 2016, 193, 12-13. [CrossRef] [PubMed]

175. McEvoy, C.T.; Ballard, P.L.; Ward, R.M.; Rower, J.E.; Wadhawan, R.; Hudak, M.L.; Weitkamp, J.H.; Harris, J.; Asselin, J.; Chapin, C.; et al. Dose-escalation trial of budesonide in surfactant for prevention of bronchopulmonary dysplasia in extremely low gestational age high-risk newborns (SASSIE). Pediatr. Res. 2020. [CrossRef] [PubMed]

176. Bassler, D.; Plavka, R.; Shinwell, E.S.; Hallman, M.; Jarreau, P.-H.; Carnielli, V.; Van den Anker, J.N.; Meisner, C.; Engel, C.; Schwab, M.; et al. early inhaled budesonide for the prevention of bronchopulmonary dysplasia. N. Engl. J. Med. 2015, 373, 1497-1506. [CrossRef] [PubMed]

177. Shah, V.S.; Ohlsson, A.; Halliday, H.L.; Dunn, M. Early administration of inhaled corticosteroids for preventing chronic lung disease in very low birth weight preterm neonates. Cochrane Database Syst. Rev. 2017, 2017, CD001969. [CrossRef]

178. Bassler, D.; Shinwell, E.S.; Hallman, M.; Jarreau, P.H.; Plavka, R.; Carnielli, V.; Meisner, C.; Engel, C.; Koch, A.; Kreutzer, K.; et al. Long-term effects of inhaled budesonide for bronchopulmonary dysplasia. N. Engl. J. Med. 2018, 378, 148-157. [CrossRef]

179. A Clinical Efficacy and Safety Study of SHP607 in Preventing Chronic Lung Disease in Extremely Premature Infants-Full Text View-ClinicalTrials.gov. Available online: https:/clinicaltrials.gov/ct2/ show/NCT03253263?term=IGF-1\&cond=Bronchopulmonary + Dysplasia\&draw $=2 \&$ rank=2 $($ accessed on 28 April 2020).

180. Wallace, B.; Peisl, A.; Seedorf, G.; Nowlin, T.; Kim, C.; Bosco, J.; Kenniston, J.; Keefe, D.; Abman, S.H. Anti-sFlt-1 therapy preserves lung alveolar and vascular growth in antenatal models of bronchopulmonary dysplasia. Am. J. Respir. Crit. Care Med. 2018, 197, 776-787. [CrossRef] 
181. Horwitz, E.M.; Le Blanc, K.; Dominici, M.; Mueller, I.; Slaper-Cortenbach, I.; Marini, F.C.; Deans, R.J.; Krause, D.S.; Keating, A. Clarification of the nomenclature for MSC: The international society for cellular therapy position statement. Cytotherapy 2005, 7, 393-395. [CrossRef]

182. Dominici, M.; Le Blanc, K.; Mueller, I.; Slaper-Cortenbach, I.; Marini, F.C.; Krause, D.S.; Deans, R.J.; Keating, A.; Prockop, D.J.; Horwitz, E.M. Minimal criteria for defining multipotent mesenchymal stromal cells. The International Society for Cellular Therapy position statement. Cytotherapy 2006, 8, 315-317. [CrossRef]

183. Wagner, D.E.; Cardoso, W.V.; Gilpin, S.E.; Majka, S.; Ott, H.; Randell, S.H.; Thébaud, B.; Waddell, T.; Weiss, D.J. An official american thoracic society workshop report 2015. Stem cells and cell therapies in lung biology and diseases. Ann. Am. Thorac. Soc. 2016, 13, S259-S278. [CrossRef]

184. Nitkin, C.R.; Bonfield, T.L. Concise review: Mesenchymal stem cell therapy for pediatric disease: Perspectives on success and potential improvements. Stem Cells Transl. Med. 2017, 6, 539-565. [CrossRef]

185. Hansmann, G.; Fernandez-Gonzalez, A.; Aslam, M.; Vitali, S.H.; Martin, T.; Mitsialis, S.A.; Kourembanas, S. Mesenchymal stem cell-mediated reversal of bronchopulmonary dysplasia and associated pulmonary hypertension. Pulm. Circ. 2012, 2, 170-181. [CrossRef]

186. Aslam, M.; Baveja, R.; Liang, O.D.; Fernandez-Gonzalez, A.; Lee, C.; Mitsialis, S.A.; Kourembanas, S. Bone marrow stromal cells attenuate lung injury in a murine model of neonatal chronic lung disease. Am. J. Respir. Crit. Care Med. 2009, 180, 1122-1130. [CrossRef]

187. Van Haaften, T.; Byrne, R.; Bonnet, S.; Rochefort, G.Y.; Akabutu, J.; Bouchentouf, M.; Rey-Parra, G.J.; Galipeau, J.; Haromy, A.; Eaton, F.; et al. Airway delivery of mesenchymal stem cells prevents arrested alveolar growth in neonatal lung injury in rats. Am. J. Respir. Crit. Care Med. 2009, 180, 1131-1142. [CrossRef]

188. Sutsko, R.P.; Young, K.C.; Ribeiro, A.; Torres, E.; Rodriguez, M.; Hehre, D.; Devia, C.; McNiece, I.; Suguihara, C. Long-term reparative effects of mesenchymal stem cell therapy following neonatal hyperoxia-induced lung injury. Pediatr. Res. 2013, 73, 46-53. [CrossRef]

189. Tropea, K.A.; Leder, E.; Aslam, M.; Lau, A.N.; Raiser, D.M.; Lee, J.-H.; Balasubramaniam, V.; Fredenburgh, L.E.; Alex Mitsialis, S.; Kourembanas, S.; et al. Bronchioalveolar stem cells increase after mesenchymal stromal cell treatment in a mouse model of bronchopulmonary dysplasia. Am. J. Physiol. Lung Cell. Mol. Physiol. 2012, 302, L829-L837. [CrossRef]

190. Zhang, X.; Wang, H.; Shi, Y.; Peng, W.; Zhang, S.; Zhang, W.; Xu, J.; Mei, Y.; Feng, Z. Role of bone marrow-derived mesenchymal stem cells in the prevention of hyperoxia-induced lung injury in newborn mice. Cell Biol. Int. 2012, 36, 589-594. [CrossRef]

191. Zhang, H.; Fang, J.; Su, H.; Yang, M.; Lai, W.; Mai, Y.; Wu, Y. Bone marrow mesenchymal stem cells attenuate lung inflammation of hyperoxic newborn rats. Pediatr. Transplant. 2012, 16, 589-598. [CrossRef]

192. Zhang, H.; Fang, J.; Wu, Y.; Mai, Y.; Lai, W.; Su, H. Mesenchymal stem cells protect against neonatal rat hyperoxic lung injury. Expert Opin. Biol. Ther. 2013, 13, 817-829. [CrossRef]

193. Gülaşı, S.; Atıcı, A.; Yılmaz, Ş.N.; Polat, A.; Yılmaz, M.; Laçin, M.T.; Örekici, G.; Çelik, Y. Mesenchymal stem cell treatment in hyperoxia-induced lung injury in newborn rats. Pediatr. Int. 2016, 58, 206-213. [CrossRef]

194. Pierro, M.; Ionescu, L.; Montemurro, T.; Vadivel, A.; Weissmann, G.; Oudit, G.; Emery, D.; Bodiga, S.; Eaton, F.; Péault, B.; et al. Short-term, long-term and paracrine effect of human umbilical cord-derived stem cells in lung injury prevention and repair in experimental bronchopulmonary dysplasia. Thorax 2013, 68, 475-484. [CrossRef]

195. Braun, R.K.; Chetty, C.; Balasubramaniam, V.; Centanni, R.; Haraldsdottir, K.; Hematti, P.; Eldridge, M.W. Intraperitoneal injection of MSC-derived exosomes prevent experimental bronchopulmonary dysplasia. Biochem. Biophys. Res. Commun. 2018, 503, 2653-2658. [CrossRef]

196. Moreira, A.; Winter, C.; Joy, J.; Winter, L.; Jones, M.; Noronha, M.; Porter, M.; Quim, K.; Corral, A.; Alayli, Y.; et al. Intranasal delivery of human umbilical cord Wharton's jelly mesenchymal stromal cells restores lung alveolarization and vascularization in experimental bronchopulmonary dysplasia. Stem Cells Transl. Med. 2019, 9, 221-234. [CrossRef] [PubMed]

197. Curley, G.F.; Hayes, M.; Ansari, B.; Shaw, G.; Ryan, A.; Barry, F.; O’Brien, T.; O’Toole, D.; Laffey, J.G. Mesenchymal stem cells enhance recovery and repair following ventilator-induced lung injury in the rat. Thorax 2012, 67, 496-501. [CrossRef]

198. Chen, C.-M.; Chou, H.-C. Human mesenchymal stem cells attenuate hyperoxia-induced lung injury through inhibition of the renin-angiotensin system in newborn rats. Am. J. Transl. Res. 2018, 10, 2628-2635. [PubMed] 
199. Kim, Y.E.; Park, W.S.; Sung, D.K.; Ahn, S.Y.; Sung, S.I.; Yoo, H.S.; Chang, Y.S. Intratracheal transplantation of mesenchymal stem cells simultaneously attenuates both lung and brain injuries in hyperoxic newborn rats. Pediatr. Res. 2016, 80, 415-424. [CrossRef] [PubMed]

200. O’Reilly, M.; Möbius, M.A.; Vadivel, A.; Ionescu, L.; Fung, M.; Eaton, F.; Greer, J.J.; Thébaud, B. Late rescue therapy with cord-derived mesenchymal stromal cells for established lung injury in experimental bronchopulmonary dysplasia. Stem Cells Dev. 2020, 29. scd.2019.0116. [CrossRef]

201. Chang, Y.S.; Ahn, S.Y.; Yoo, H.S.; Sung, S.I.; Choi, S.J.; Oh, W.I.; Park, W.S. Mesenchymal stem cells for bronchopulmonary dysplasia: Phase 1 dose-escalation clinical trial. J. Pediatr. 2014, 164, 966-972. [CrossRef]

202. Powell, S.B.; Silvestri, J.M. Safety of intratracheal administration of human umbilical cord blood derived mesenchymal stromal cells in extremely low birth weight preterm infants. J. Pediatr. 2019, 210, 209-213. [CrossRef]

203. Ahn, S.Y.; Chang, Y.S.; Kim, J.H.; Sung, S.I.; Park, W.S. Two-year follow-up outcomes of premature infants enrolled in the phase I trial of mesenchymal stem cells transplantation for bronchopulmonary dysplasia. J. Pediatr. 2017, 185, 49-54. [CrossRef]

204. Hodges, R.J.; Jenkin, G.; Hooper, S.B.; Allison, B.; Lim, R.; Dickinson, H.; Miller, S.L.; Vosdoganes, P.; Wallace, E.M. Human amnion epithelial cells reduce ventilation-induced preterm lung injury in fetal sheep. Am. J. Obstet. Gynecol. 2012, 206, 448.e8-448.e15. [CrossRef]

205. Carraro, G.; Perin, L.; Sedrakyan, S.; Giuliani, S.; Tiozzo, C.; Lee, J.; Turcatel, G.; De Langhe, S.P.; Driscoll, B.; Bellusci, S.; et al. Human amniotic fluid stem cells can integrate and differentiate into epithelial lung lineages. Stem Cells 2008, 26, 2902-2911. [CrossRef] [PubMed]

206. Grisafi, D.; Pozzobon, M.; Dedja, A.; Vanzo, V.; Tomanin, R.; Porzionato, A.; Macchi, V.; Salmaso, R.; Scarpa, M.; Cozzi, E.; et al. Human amniotic fluid stem cells protect rat lungs exposed to moderate hyperoxia. Pediatr. Pulmonol. 2013, 48, 1070-1080. [CrossRef] [PubMed]

207. Lim, R.; Malhotra, A.; Tan, J.; Chan, S.T.; Lau, S.; Zhu, D.; Mockler, J.C.; Wallace, E.M. First-in-human administration of allogeneic amnion cells in premature infants with bronchopulmonary dysplasia: A safety study. Stem Cells Transl. Med. 2018. [CrossRef] [PubMed]

208. Malhotra, A.; Lim, R.; Mockler, J.C.; Wallace, E.M. Two-year outcomes of infants enrolled in the first-in-human study of amnion cells for bronchopulmonary dysplasia. Stem Cells Transl. Med. 9 Mar. 2019, 289-294. [CrossRef]

209. Doorn, J.; Moll, G.; Le Blanc, K.; van Blitterswijk, C.; de Boer, J. Therapeutic applications of mesenchymal stromal cells: Paracrine effects and potential improvements. Tissue Eng. Part. B Rev. 2012, 18, 101-115. [CrossRef]

210. Liang, X.; Ding, Y.; Zhang, Y.; Tse, H.F.; Lian, Q. Paracrine mechanisms of mesenchymal stem cell-based therapy: Current status and perspectives. Cell Transplant. 2014, 23, 1045-1059. [CrossRef]

211. Silva, A.M.; Teixeira, J.H.; Almeida, M.I.; Gonçalves, R.M.; Barbosa, M.A.; Santos, S.G. Extracellular Vesicles: Immunomodulatory messengers in the context of tissue repair/regeneration. Eur. J. Pharm. Sci. 2017, 98, 86-95. [CrossRef]

212. Lötvall, J.; Hill, A.F.; Hochberg, F.; Buzás, E.I.; Vizio, D.D.; Gardiner, C.; Gho, Y.S.; Kurochkin, I.V.; Mathivanan, S.; Quesenberry, P.; et al. Minimal experimental requirements for definition of extracellular vesicles and their functions: A position statement from the International Society for Extracellular Vesicles. J. Extracell. Vesicles 2014, 3, 26913. [CrossRef]

213. Vlassov, A.V.; Magdaleno, S.; Setterquist, R.; Conrad, R. Exosomes: Current knowledge of their composition, biological functions, and diagnostic and therapeutic potentials. Biochim. Biophys. Acta Gen. Subj. 2012, 1820, 940-948. [CrossRef]

214. Del Fattore, A.; Luciano, R.; Pascucci, L.; Goffredo, B.M.; Giorda, E.; Scapaticci, M.; Fierabracci, A.; Muraca, M. Immunoregulatory effects of mesenchymal stem cell-derived extracellular vesicles on T lymphocytes. Cell Transplant. 2015, 24, 2615-2627. [CrossRef]

215. Di Trapani, M.; Bassi, G.; Midolo, M.; Gatti, A.; Kamga, P.T.; Cassaro, A.; Carusone, R.; Adamo, A.; Krampera, M. Differential and transferable modulatory effects of mesenchymal stromal cell-derived extracellular vesicles on T, B and NK cell functions. Sci. Rep. 2016, 6, 24120. [CrossRef] [PubMed] 
216. Fukui, T.; Matsumoto, T.; Mifune, Y.; Shoji, T.; Kuroda, T.; Kawakami, Y.; Kawamoto, A.; Ii, M.; Kawamata, S.; Kurosaka, M.; et al. Local transplantation of granulocyte colony-stimulating factor-mobilized human peripheral blood mononuclear cells for unhealing bone fractures. Cell Transplant. 2012, 21, 707-721. [CrossRef] [PubMed]

217. El Andaloussi, S.; Mäger, I.; Breakefield, X.O.; Wood, M.J.A. Extracellular vesicles: Biology and emerging therapeutic opportunities. Nat. Rev. Drug Discov. 2013, 12, 347-357. [CrossRef] [PubMed]

218. Fierabracci, A.; Del Fattore, A.; Luciano, R.; Muraca, M.M.; Teti, A.; Muraca, M.M. Recent advances in mesenchymal stem cell immunomodulation: The role of microvesicles. Cell Transplant. 2015, 24, 133-149. [CrossRef]

219. Phinney, D.G.; Pittenger, M.F. Concise review: MSC-derived exosomes for cell-free therapy. Stem Cells 2017, 35, 851-858. [CrossRef]

220. Chaubey, S.; Thueson, S.; Ponnalagu, D.; Alam, M.A.; Gheorghe, C.P.; Aghai, Z.; Singh, H.; Bhandari, V. Early gestational mesenchymal stem cell secretome attenuates experimental bronchopulmonary dysplasia in part via exosome-associated factor TSG-6. Stem Cell Res. Ther. 2018, 9, 173. [CrossRef]

221. Ahn, S.Y.; Park, W.S.; Kim, Y.E.; Sung, D.K.; Sung, S.I.; Ahn, J.Y.; Chang, Y.S. Vascular endothelial growth factor mediates the therapeutic efficacy of mesenchymal stem cell-derived extracellular vesicles against neonatal hyperoxic lung injury. Exp. Mol. Med. 2018, 50, 26. [CrossRef]

222. Willis, G.R.; Fernandez-Gonzalez, A.; Anastas, J.; Vitali, S.H.; Liu, X.; Ericsson, M.; Kwong, A.; Mitsialis, S.A.; Kourembanas, S. Mesenchymal stromal cell exosomes ameliorate experimental bronchopulmonary dysplasia and restore lung function through macrophage immunomodulation. Am. J. Respir. Crit. Care Med. 2018, 197, 104-116. [CrossRef]

223. Lee, C.; Mitsialis, S.A.; Aslam, M.; Vitali, S.H.; Vergadi, E.; Konstantinou, G.; Sdrimas, K.; Fernandez-Gonzalez, A.; Kourembanas, S. Exosomes mediate the cytoprotective action of mesenchymal stromal cells on hypoxia-induced pulmonary hypertension. Circulation 2012, 126, 2601-2611. [CrossRef]

224. Muraca, M.; Piccoli, M.; Franzin, C.; Tolomeo, A.; Jurga, M.; Pozzobon, M.; Perilongo, G. Diverging concepts and novel perspectives in regenerative medicine. Int. J. Mol. Sci. 2017, 18, 1021. [CrossRef]

225. Zhu, Y.; Feng, X.; Abbott, J.; Fang, X.; Hao, Q.; Monsel, A.; Qu, J.; Matthay, M.A.; Lee, J.W. Human Mesenchymal Stem Cell Microvesicles for Treatment of Escherichia coli Endotoxin-Induced Acute Lung Injury in Mice. Stem Cells 2014, 32, 116-125. [CrossRef]

226. Morse, M.A.; Garst, J.; Osada, T.; Khan, S.; Hobeika, A.; Clay, T.M.; Valente, N.; Shreeniwas, R.; Sutton, M.A.; Delcayre, A.; et al. A phase I study of dexosome immunotherapy in patients with advanced non-small cell lung cancer. J. Transl. Med. 2005, 3, 9. [CrossRef]

227. Escudier, B.; Dorval, T.; Chaput, N.; André, F.; Caby, M.P.; Novault, S.; Flament, C.; Leboulaire, C.; Borg, C.; Amigorena, S.; et al. Vaccination of metastatic melanoma patients with autologous dendritic cell (DC) derived-exosomes: Results of the first phase 1 clinical trial. J. Transl. Med. 2005, 3, 10. [CrossRef]

228. Kordelas, L.; Rebmann, V.; Ludwig, A.K.; Radtke, S.; Ruesing, J.; Doeppner, T.R.; Epple, M.; Horn, P.A.; Beelen, D.W.; Giebel, B. MSC-derived exosomes: A novel tool to treat therapy-refractory graft-versus-host disease. Leukemia 2014, 28, 970-973. [CrossRef]

229. Gao, J.; Dong, X.; Wang, Z. Generation, purification and engineering of extracellular vesicles and their biomedical applications. Methods 2019, 177, 114-125. [CrossRef]

230. Ramasubramanian, L.; Kumar, P.; Wang, A. Engineering extracellular vesicles as nanotherapeutics for regenerative medicine. Biomolecules 2020, 10, 48. [CrossRef]

231. Rüdiger, M.; Kirpalani, H.; Steinhorn, R.; Davis, J.M.; Thebaud, B. How to introduce MSC-based therapy for the developing lung safely into clinical care? Pediatr. Res. 2020. [CrossRef]

232. Muraca, M.; Zaramella, P.; Porzionato, A.; Baraldi, E. Exosome treatment of bronchopulmonary dysplasia. how pure should your exosome preparation be? Am. J. Respir. Crit. Care Med. 2017, 197, 969-970. [CrossRef]

(C) 2020 by the authors. Licensee MDPI, Basel, Switzerland. This article is an open access article distributed under the terms and conditions of the Creative Commons Attribution (CC BY) license (http://creativecommons.org/licenses/by/4.0/). 